NBER WORKING PAPER SERIES

\title{
SHARED CAPITALISM IN THE U.S. ECONOMY? PREVALENCE, CHARACTERISTICS, AND EMPLOYEE VIEWS OF FINANCIAL PARTICIPATION IN ENTERPRISES
}

\author{
Douglas L. Kruse \\ Joseph R. Blasi \\ Rhokeun Park \\ Working Paper 14225 \\ http://www.nber.org/papers/w14225
}

\author{
NATIONAL BUREAU OF ECONOMIC RESEARCH \\ 1050 Massachusetts Avenue \\ Cambridge, MA 02138 \\ August 2008
}

Presented at the Russell Sage/NBER conference in New York City, October 2006. We thank Casey Ichniowski for valuable comments. This paper is part of the National Bureau of Economic Research's Shared Capitalism Research Project, funded by the Russell Sage and Rockefeller Foundations. Additional funding for the General Social Survey questions was provided by the Beyster Institute of the University of California at San Diego, the ESOP Association, the Employee Ownership Foundation, Hewitt Associates, the National Center for Employee Ownership, the Profit Sharing Council of America, and American Capital. The authors wish to thank Tom Smith with the General Social Survey at the National Opinion Research Center of the University of Chicago and Peter Marsden of Harvard University with the National Organizations Study for their assistance in arranging the shared capitalism segment of both surveys. Refen Koh, Michelle Pinheiro, and Patricia Berhau provided excellent assistance in survey scanning, entry, and verification. The views expressed herein are those of the author(s) and do not necessarily reflect the views of the National Bureau of Economic Research.

NBER working papers are circulated for discussion and comment purposes. They have not been peerreviewed or been subject to the review by the NBER Board of Directors that accompanies official NBER publications.

(C) 2008 by Douglas L. Kruse, Joseph R. Blasi, and Rhokeun Park. All rights reserved. Short sections of text, not to exceed two paragraphs, may be quoted without explicit permission provided that full credit, including $\odot$ notice, is given to the source. 
Shared Capitalism in the U.S. Economy: Prevalence, Characteristics, and Employee Views of Financial Participation in Enterprises

Douglas L. Kruse, Joseph R. Blasi, and Rhokeun Park

NBER Working Paper No. 14225

August 2008

JEL No. J33,J54,L23

\begin{abstract}
Between one-third and one-half of employees participate directly in company performance through profit sharing, gainsharing, employee ownership, or stock options. This flies in the face of concerns about the free rider problem and worker risk aversion in group incentives, and raises many questions about the effects on firms and workers. This paper lays out the major reasons we may see such "shared capitalism" plans, and reviews recent nationally representative surveys on the prevalence of these plans. We also introduce the NBER shared capitalism data, based on questions added to the 2002 and 2006 General Social Surveys (GSS) and more than 40,000 employee surveys from 14 companies with different combinations of shared capitalism plans. We find that while shared capitalism exists broadly throughout the economy, it is more likely in larger establishments. The free rider effect may be countered by the use of other policies to create productive teamwork and a cooperative culture: shared capitalism is positively linked to workplace decision-making, training, job security, teamwork, the ability to easily observe co-worker performance, and low levels of supervision. Also, more risk-averse employees avoid participating in several types of shared capitalism, but two-thirds of even the most risk-averse employees in these companies say they want shared capitalism as part of their pay package. The effects of these plans for both workers and firms are more fully explored in accompanying papers.
\end{abstract}

\author{
Douglas L. Kruse \\ School of Management and Labor Relations \\ Rutgers University \\ 94 Rockafeller Road \\ Piscataway, NJ 08854 \\ and NBER \\ dkruse@rci.rutgers.edu \\ Joseph R. Blasi \\ Rutgers University \\ School of Management and Labor Relations \\ Levin Building \\ New Brunswick, NJ 08544 \\ and NBER \\ jrbru@hotmail.com
}

Rhokeun Park

Kwangwoon University

26 Kwangwoon-gil, Nowon-gu

Seoul, Korea 139-701

rhokeun@kw.ac.kr 
In the past several decades the U.S. and other advanced countries have seen growth in direct employee participation in the financial performance of capitalist enterprises. This participation can take many forms, including profit sharing, gain sharing, bonuses, employee stock ownership, and broad-based stock options. All of these approaches have one thing in common: offering the worker a share in profits or stock appreciation when the company makes a profit. Our broad label for this participation is "shared capitalism."

This growth is driven in part by increased competitive pressures, environmental volatility, and rapid technological change, which have led firms to implement new forms of workplace organization and human resource practices. These changes include increased teamwork, employee participation in decisions, and other practices that can work in conjunction with financial participation to increase worker productivity, skills, commitment, and job security. Shared capitalist institutions with new forms of high performance work organization, not traditional labor-management relations, may be the emerging form of employee relations under capitalism.

This raises a number of important questions for firms, workers, and economic policymakers:

- $\quad$ To what extent are these new modes of financial participation and decision-making related?

- $\quad$ Are they likely to increase or decrease economic inequality?

- Do they generally supplement or substitute for standard forms of compensation?

- How can they best improve productivity in ways that will benefit both firms and ordinary workers?

- $\quad$ Do employees welcome shared capitalism or are they uneasy about the increased 
financial risk and responsibility that this places on them?

- $\quad$ Are the new forms of participation likely to continue to grow?

This paper introduces the NBER project that was established to address these questions. Following a discussion of why shared capitalism exists at all, we summarize data on the current forms and extent of shared capitalism in the U.S. economy. We then introduce the General Social Survey and NBER employee survey datasets that will be used to answer the above questions in accompanying papers ${ }^{1}$, and provide an overall portrait of the data and an initial exploration of how shared capitalism is related to job and company characteristics, work organization, risk aversion, and worker preferences.

\section{Why Share with Workers?}

Standard economic analysis outlines two key problems with shared capitalism plans that argue against their use. Principal-agent analysis says that owners/managers can improve employees' performance by giving employees pay contingent on performance, but group incentives suffer from the free rider or " $1 / \mathrm{N}$ " problem due to the increasingly weak link between individual performance and rewards as the size of the group expands. Economic analysis therefore predicts that firms will favor tying financial rewards to local economic performance and outcomes rather than to company-wide outcomes. This is because profit-sharing or gainsharing based on workplace outcomes can motivate workers in a small group, who can influence the costs and revenues of that group. Hence, the argument suggests that firms that introduce financial sharing should eschew company-wide sharing, since there is virtually nothing the local

1 The accompanying papers using the GSS and NBER survey data are Blasi, Kruse, and Markowitz (2008), Blasi et al. (2008), Buchele et al. (2008), Budd (2008), Carberry (2008), Freeman, Kruse, and Blasi (2008), Harden, Kruse, and Blasi (2008), and Kruse, Freeman, and Blasi (2008). These issues are addressed using additional U.S. and UK 
group can do to affect the share price of the firm.

A second key problem with shared capitalism plans is income variability for risk-averse workers. Firms are predicted to select the least costly form of rewarding workers. In traditional analyses where firms are risk-neutral and workers are risk-averse, this means paying employees wages or salaries, rather than with variable pay dependent on company performance. Firms that offer more risky modes of wage payment should have to compensate workers for risk.

Given these (and other ${ }^{2}$ ) problems, why are there any shared capitalism plans? The major reasons for adopting shared capitalism can be categorized as productivity- or flexibilityrelated.

Productivity reasons for shared capitalism plans

Firms may find that group incentives are better than individual incentives for encouraging productive teamwork and information sharing, especially where centralized supervision is costly. The free rider problem may be overcome by creation of an implicit cooperative agreement among employees to work hard, enforced by monitoring co-worker performance and applying peer pressure where needed (Weitzman and Kruse, 1990). What it takes to create and maintain such an agreement is unclear and may vary from workplace to workplace_-it is likely that company human resource policies, employee relations, and general corporate culture play a large role. A growing body of literature finds that combinations of workplace policies may induce behaviours that improve performance (see, e.g., Ichniowski et al.

datasets in Bryson and Freeman (2008) and Dube and Freeman (2008).

2 While these are the two most common theoretical objections to shared capitalism plans, there are others as well. These include the possibility that diluting the economic surplus received by the owner will decrease performance by weakening the owner's incentive to monitor workers closely (Alchian and Demsetz, 1972), and the objection that profit sharing will decrease the firm's incentives to make capital investments (Summers, 1986). See Putterman and Skillman (1988) and Weitzman (1986) for responses to these, and Bonin and Putterman (1987) and Dow (2003) for additional theoretical arguments for and against shared capitalism plans. 
1996). It has been demonstrated that globalization in specific industries and firms is linked to the adoption of high performance work practices in firms in specific industries (Blasi and Kruse, 2006).

A productivity motivation for adopting and maintaining shared capitalism plans is directly expressed by many firms (U.S. GAO, 1986: 20; Kruse, 1993: 33), and is supported by several findings in studies of adoption. ${ }^{3}$ Studies generally find, however, that profit-sharing and employee ownership plans are more common in large firms, which runs counter to the idea that the free rider problem will favor greater productivity in small firms. ${ }^{4}$

Shared capitalism does appear to create productive cooperation at least in some companies. Existing evidence from over 60 studies indicates a positive association on average between shared capitalism programs and company performance, but with substantial dispersion in results (Kruse and Blasi, 1997; Kruse, 2002). The average estimated increase in productivity associated with employee ownership and profit sharing is about $4.5 \%$, and is maintained when using pre/post comparisons and attempts to control for selection bias. Boning, Ichniowski, and Shaw (2001) find positive effects of group incentives, particularly when combined with problemsolving teams. Other studies of gainsharing also find positive results, particularly when there is high employee involvement in design and operation, shorter pay out periods, controllable targets, and perceptions of procedural and distributive justice (Bullock and Tubbs, 1990; Collins, 1998). Many of the effects of shared capitalism plans on performance are likely to work through

3 Oyer and Schaefer (2005) find that adoption of broad-based stock option plans can be explained by retention and sorting, but not incentive effects. Kruse (1996) finds that R\&D levels are higher among old profit-sharing firms, and job enrichment plans were more likely to be adopted just before new profit-sharing plans, suggesting complementarities aimed at improving productivity. Beatty (1994) finds that risk variables suggest a productivity motivation for adoption of ESOPs. Ichniowski and Shaw (1995) find that group incentives are more likely to be adopted when they are part of a package of complementary policies to improve productivity, and also find evidence of large switching costs that discourage firms with established technologies and workplace relationships from 
employee attitudes and behaviours. ${ }^{5}$ Most studies find that organizational commitment and identification are higher under employee ownership, while giving mixed results between favorable and neutral on motivation and behavioral measures (Kruse and Blasi, 1997). The results are consistent with opinion polls which find that most members of the public think that workers in employee ownership firms work harder and better (reviewed in Kruse and Blasi, 1999).

Flexibility reasons for shared capitalism plans

Firms may also adopt shared capitalism plans for flexibility-related reasons. These plans can provide something of value to workers without a fixed obligation (such as a wage or salary increase) that the company may have difficulty meeting depending on future performance and the competitive environment. A flexibility motivation is supported by the finding that increased volatility in profits helps predict adoption of profit sharing and employee ownership plans (Kruse, 1996), although another study found that low-risk firms are more likely to provide company stock matches in 401(k) plans (Brown et al., 2004).

Some of the firm's financial risk is being shared with workers, which as noted above may disadvantage risk-averse workers unless they are compensated for the risk. Consistent with the idea that workers are risk averse, most prefer straight wage salary to company-wide or individual incentives; however, a majority express positive views toward employee ownership and profit sharing, and would like at least part of their next raise to be in company stock (summarized in Kruse and Blasi, 1999). The extant evidence indicates that workers generally do not sacrifice pay and benefits for shared capitalism plans: wages and compensation tend to be higher on

adopting new practices.

4 See Gregg and Machin (1988), Poole (1989), Fitzroy and Kraft (1995), and Kruse (1996).

5 Bartel et al. (2003) find that employee attitudes affect a variety of workplace outcomes. 
average for workers in employee ownership and profit sharing plans (Blasi et al., 1996; Kardas et al., 1998; Kruse, 1993: 113-114; Kruse, 1998; Scharf and Mackin, 2000). In exchange for the financial risk, workers may benefit through lower risk of displacement: prior studies find that employee ownership firms tend to have more stable employment and higher survival rates than other firms (Craig and Pencavel, 1992, 1993; Blair et al., 2000; Park et al., 2004). The prediction by Weitzman (1984) that profit sharing should stabilize firm employment has also received support in many, though not all, studies. ${ }^{6}$

Other reasons for shared capitalism plans

There are several reasons that firms may adopt shared capitalism plans apart from those that are productivity- or flexibility-related. First, firms may adopt such plans due to tax and regulatory incentives - for example, ESOPs enjoyed substantial tax incentives in the 1980's, and retiring owners can still avoid capital gains taxes if they sell their stock to an ESOP. Second, some employee ownership plans were adopted in the 1980's in response to hostile takeover threats (Blasi and Kruse, 1991). Both takeover threats and tax incentives were clearly a factor in some 1980's ESOP adoptions (Blasi and Kruse, 1991; Beatty, 1994). Third, firms may adopt employee ownership or profit sharing out of a desire to discourage unionization by increasing employee identification with the company. Profit sharing plans are less common among unionized workers, which at least partly reflects firms dropping such plans after a union drive (Freeman and Kleiner, 1990; Mitchell et al., 1990; Kruse, 1996). Findings are mixed on the

6 Studies of Weitzman's prediction that profit sharing should stabilize firm employment have produced mixed findings: a majority support the proposition that firms view profit sharing differently from fixed wages in making employment decisions, while half of the studies find greater employment stability associated with profit sharing and the other half find either no greater stability or greater stability only in some samples (summarized in Kruse, 1998: 109-113). 
relation between unionization and employee ownership. ${ }^{7}$

Finally, shared capitalism plans may be adopted and promoted for moral or social reasons. Albert Gallatin, a signer of the Declaration of Independence and Secretary of the Treasury under Thomas Jefferson, set up a profit sharing plan at the Pennsylvania Glass Works in 1795, stating that the "democratic principle upon which this Nation was founded should not be restricted to the political processes but should be applied to the industrial operation" (quoted in U.S. Senate 1939: 72). Workers who started the first unions in colonial American coastal cities set up some worker cooperatives as alternatives to the craft firms where some master craftsmen were attempting to introduce more division of labor in order to de-skill traditional craft workers and reduce their pay. A century later, some labor organizations set up worker cooperatives as part of a political challenge to how capitalism was developing, while others saw employee ownership and profit sharing as a means to build support for capitalism in opposition to the competing communist and socialist systems_-arguing that it would help cure "unrest" and "irrational agitation" in capitalism, and that the "great uplift and inspiration that sharing of profits cultivates in the employee" would lead to "harmony and contentment" (Askwith, 1926: 20). John D. Rockefeller and other corporate leaders in 1919 encouraged employee ownership, employee involvement in corporate decision-making, and profit sharing as part of a grand plan for "welfare capitalism" that spread in the 1920's. Profit sharing was promoted in the 1930's in Congressional hearings in the 1930's by Republican Senator Arthur Vandenberg, and ESOPs were promoted by investment banker Louis Kelso in conjunction with Democratic Senator

7 Gregg and Machin (1988) and Poole (1989) find employee ownership is more common in unionized companies in the UK, while Kruse (1996) finds that ESOP adoption was equally likely in union and non-union establishments in the 1970's and 1980's. 
Russell Long of Louisiana in the 1970's, as ways to broaden participation in the economic system. $^{8}$

In sum, the two key objections to group incentives - the free rider problem and worker risk aversion — have not been sufficient to quash shared capitalism plans. They continue to be adopted and maintained, providing a fertile ground for examining outcomes for both firms and workers. As will be seen, such programs now involve over a third of adult workers in the economy, albeit at different levels of intensity and with different combinations of work practices. The next section reviews current data on the prevalence of shared capitalism plans, followed by a more intensive look at the kind of company policies associated with shared capitalism that can shed light on how they are used by companies.

\section{Prevalence of Shared Capitalism Programs}

There are a variety of forms that shared capitalism programs can take, which we break into four broad categories: profit sharing, gainsharing, employee ownership, and stock options. The NBER Shared Capitalism program sponsored several questions on shared capitalism in the 2002 and 2006 General Social Surveys and the 2003 National Organizations Survey, providing the most recent representative data available. The results from these surveys are summarized in Table 1, while Appendix Table A-1 summarizes other nationally representative surveys and administrative data over the past 15 years. All of the surveys have high response rates. Four of the surveys were conducted by the U.S. Census Bureau (the two National Employer Surveys, the National Compensation Survey and the National Longitudinal Survey of Youth), two surveys were conducted by the National Opinion Research Center of the University of Chicago (General

8 For a more extensive history of shared capitalism see Blasi, Kruse, and Bernstein (2003). 
Social Survey and National Organizations Survey), and two were conducted by professional survey organizations (the Worker Representation and Participation Survey by Princeton Survey Research Associates, and the Employee Benefits Research Institute survey by Gallup). All surveys are based on the full private sector, except the National Employer Surveys which are limited to private for-profit firms. ${ }^{9}$

There is no hard and fast definition of profit sharing. Many firms have formal plans that are called profit sharing, but there is variation in a) how profits are defined, b) whether profits must meet a threshold level, c) whether some or all of the profit share is discretionary, and d) whether the profit share is paid in cash or is deferred (put into a defined contribution pension plan). In addition, firms may have bonus plans that are not called profit sharing, but which effectively share profits since the bonus is affected by how well the company is doing. As shown in Table 1, just over one-third of employees say that they are covered by profit sharing in 2002 (34\%) and 2006 (38\%), which is in line with earlier employee surveys in Table A-1. Employers reported a higher percentage of employees eligible for bonuses based on company performance (46\%), though another survey using a more restricted definition showed lower figures (30\% of workers are in a deferred profit-sharing plan while $5 \%$ are in a cash profit sharing plan, in Table A-1).

Gainsharing plans typically tie employee compensation to a group-based operational measure -- such as physical output, productivity, quality, safety, customer satisfaction, or costs -rather than to a company-wide financial measure such as profitability or returns. These plans often involve employees in some formal way to develop ideas and skills for improving

9 The full private sector figures include non-profit organizations. While these organizations cannot have employee ownership and stock options, they can have organization- and group-based bonuses that are equivalent to profit sharing and gainsharing, so their inclusion provides the best estimates of the extent to which shared capitalism has 
performance. The three most popular types are Scanlon, Rucker, and ImproShare plans, although there is a growing number of custom-designed plans. As shown in Table 1, employee and company surveys agree that about one-fourth (23-27\%) of employees are eligible for bonuses based on group or workplace performance. ${ }^{10}$

Employee ownership of company stock can occur in a variety of ways. Combining all the ways, the GSS surveys in Table 1 show that roughly one-fifth of employees report owning some company stock (21\% in 2002 and 18\% in 2006, which is in line with earlier surveys in Table A-1). The most popular type of plan is the ESOP (Employee Stock Ownership Plan). The ESOP is distinguished by the fact that workers do not have to use their own money to buy the stock (unless stock was traded for wage and work rule changes which happens only in a very small minority of ESOPs). Federal legislation allows companies to borrow money from a bank to fund the worker stock and pay for it in installments from company revenues. About $5 \%$ of employees are part of ESOPs (Table A-1). Employees may also own company stock through other types of defined contribution plans. Many employees have bought stock through their company 401(k) plan, a retirement plan where they make pre-tax contributions from their paycheck. Sometimes corporations will match employee contributions to 401(k) plans with company stock, so this type of employee ownership is closer to the ESOP because workers do not buy it. About $20 \%$ of workers are eligible for a defined contribution plan that holds employer stock (Table A-1). These non-ESOP pension plans also include various ERISAcovered stock bonus plans and deferred profit sharing trusts (often combined with 401k plans)

permeated the entire private sector. Other papers in the NBER project restrict attention to for-profit firms. 10 About two-fifths (43\%) of Fortune 1000 surveyed companies have gain-sharing plans somewhere in the company, although most include less than 20\% of employees (Lawler et al., 1995: 19). Broader surveys of compensation and human resource managers have found that only about one-eighth (13\%) have formal gainsharing plans (Collins, 1998). 
which actually hold some of their assets in company stock.

Employees can also own company stock outside of pension plans. Employee Stock Purchase Plans (ESPPs) allow workers to buy stock with deductions from their paycheck with a discount from the market price, and some corporations provide employees direct grants of stock as part of a stock bonus plan. Employees may also hold onto stock after exercising stock options, or own stock through open market purchases. These plans combine with the pension plans to make about one-fifth of private sector employees into employee-owners.

Stock options represent a kind of hybrid between profit sharing and employee ownership. A stock option is the right to buy the stock at a set price for 10 years into the future. The worker does not have to purchase the stock. Receiving one hundred stock options to purchase Biotech Inc. stock at \$10 per share gives the worker the right to exercise these options anytime over 10 years if the stock price goes above $\$ 10$ per share. During the ten years, the worker can for example buy a stock trading at \$15 a share for \$10 per share, then sell the stock, and pocket the \$5 profit after taxes. While stock option excesses have been abused among higher executives, for other managers and workers, a stock option has less risk than using one's savings to buy the stock and really involves the right to the upside gain without the risk of losing one's capital. The GSS surveys show a decline in stock option holding from 13\% in 2002 to $9 \%$ in 2006, which we believe is due to the Security and Exchange Commission’s implementation of stock option expensing that led some companies to cut back on broad-based plans. ${ }^{11}$ Only $14 \%$ of companies reported making stock option grants in 2002 and 5\% of employees in the 2006 GSS reported

11 This drop in stock option holding likely accounts for the drop in the percent of workers in the computer services industry who own company stock (from 58.3\% to 31.9\%). Because employee ownership often comes about as a result of being granted stock options, this drop is likely an unintended consequence of the employee stock option expensing. 
actually receiving a stock option grant in the prior year (Table 1), while other surveys showed that $8 \%$ of employees are eligible to receive stock options (Table A-1).

The prevalence of any type of shared capitalism is high: the GSS surveys showed that $43 \%$ of employees reported participating in one or more of the above plans in 2002, rising to 47\% in 2006 (Table 1). The rise in profit-sharing and gainsharing eligibility more than offset the declines in employee ownership and stock option holding between these two years. Earlier surveys show that between $41 \%$ and $75 \%$ of firms have shared capitalism plans (Table A-1).

What is the overlap among the different types of shared capitalism? This issue has never been comprehensively explored until the 2002 and 2006 General Social Surveys. As shown in Table 1, close to $15 \%$ of employees in the 2002 survey received a profit- or gainsharing bonus in the prior year but do not own company stock or hold stock options, rising to $21 \%$ in 2006 . There were $4-5 \%$ who just own company stock and less than $1 \%$ who just hold stock options. About $10 \%$ had two of the three forms of shared capitalism in both years, while 5-6\% had all three. The important point here is that employee ownership and stock option holding are uncommon on their own, and typically paired with another type of shared capitalism. Over three-fourths of the employee-owners also have profit/gainsharing bonuses and/or stock options, while almost all of the $13 \%$ who hold stock options also have profit/gainsharing bonuses and/or employee ownership. This high overlap suggests that firms may believe that it is worthwhile to examine employee ownership and stock options in combination with each other and profit/gainsharing.

Employee ownership and profit sharing have also received substantial attention in other advanced countries and transition economies. With coverage similar to that in the U.S., between 20\% and 30\% of workers in France, Great Britain, Italy, and Japan are covered by some 
form of profit sharing, while smaller numbers covered by employee stock ownership (Del Boca et al., 1999; Jones and Kato, 1995). Across the European Union, between 5\% and 43\% of firms within each country have profit-sharing plans, between $1 \%$ and $22 \%$ have employee share ownership, and between 5\% and 38\% have team-based bonuses (European Foundation for the Improvement of Living and Working Conditions, 1997; Pendleton et al., 2003). Some employee ownership is also found in some socialist countries transiting to private ownership, including China (Tseo, 1996), Russia (Blasi et al., 1997), and the countries in central and eastern Europe (Uvalic and Vaughan-Whitehead, 1997; Smith et al., 1997). Broad-based stock options have appeared in stock market companies and high tech firms in Asia and are newly emergent in China and India.

Employee participation in decision making is often seen as complementary to financial participation, most basically because financial participation provides the incentive to improve performance while participation in decision making can provide a means to improve performance. Before looking at their overlap in the next section, Table 2 summarizes the most recent survey data on the overall prevalence of employee participation in decisions. There is a lot of variation in the types and measures of employee participation. About two-fifths of employees report having a lot of influence in decisions or say they often participate with others in job decisions in both 2002 and 2006, while one-third of employees report being in an employee involvement team (30\%) or self-directed work team (33\%). Firms report a lower number of employees in these plans (17\% each), while about two-fifths of firms report having these plans at all. Data from earlier surveys in Table A-2 show great dispersion using different measures, from a low of $13-16 \%$ of employees in self-managed teams to a high of $52-55 \%$ of employees in work-related meetings for nonmanagers. 


\section{Looking Inside the Shared Capitalism Firms}

The current NBER project was established to take a closer look at shared capitalism plans, providing a more complete portrait along with an analysis of their causes and effects. The first component of this project was to place several questions on the 2002 and 2006 General Social Surveys, in order to collect data from a representative sample of employed Americans. The basic results were presented in Tables 1 and 2 . The second component of the project was to do a more intensive look by conducting employee surveys in a number of firms that use shared capitalism programs. Project members recruited 14 companies with a variety of shared capitalist programs, and surveys were conducted over the 2001-2006 period.

\section{The NBER database}

Basic information on the shared capitalism firms is contained in Table 3 (described only in broad terms to preserve company confidentiality). All of the firms have some sort of broadbased employee ownership plan, but the plan types vary: eight have standard ESOPs, one has a 401(k) ESOP, four have Employee Stock Purchase Plans (ESPPs), and three have 401(k)'s with company stock. Eleven of the firms have broad-based profit-sharing plans, while five have broad-based stock option plans. We also have variation by company size (six with fewer than 1000 employees and three with more than 10,000 employees), and industry (eight in manufacturing, four in service/financial, and two in high-tech/Internet).

While there is useful variance in types of companies and plans, we acknowledge that our sample is non-representative, first because many firms refused our requests to run the survey, and second because two of the firms were bought out by others who refused to proceed with the planned survey. Each company in the sample agreed to have our research group administer a 
survey to all or a random sample of employees. The survey included core questions common across all companies, and some questions of special interest or relevance to that company. Six company surveys were conducted entirely by web, seven company surveys were done on paper, and one survey was done using both the web and paper. The company response rates ranged from $11 \%$ to $80 \%$, with an average of $53 \%$ across the 14 companies. A total of 41,206 respondents provided usable surveys.

Question wordings for the GSS and NBER measures are provided in the appendix.

\section{Size of financial stakes in shared capitalism}

The extent and characteristics of shared capitalism programs in the GSS and NBER datasets are presented in Table 4. This table combines the 2002 and 2006 GSS prevalence figures from Table 1 (showing about one-third of workers covered by profit sharing, one-fourth covered by gainsharing, one-fifth holding company stock, and one-ninth holding stock options), and adds detail on the financial stakes involved. The monetary value appears to be significant for covered employees. The median profit sharing and gain sharing bonus in the GSS is $\$ 1,500$ or $4.6 \%$ of annual pay, and employer stock totals $\$ 10,000$ or $23 \%$ of annual pay for the median employee-owner.

The column labelled "NBER company dataset" naturally gives higher figures for the shared capitalist modes of compensation since we selected these firms on the basis of having these programs. Seventy-one percent of the workers in the firms report being paid by profit sharing, $21 \%$ report gain sharing, $64 \%$ report owning employer stock, and $22 \%$ report holding stock options. Overall, $86 \%$ of surveyed workers report having at least one of these programs. The size of the median profit-sharing and gain sharing stake are only somewhat higher among 
the NBER companies than in the GSS (5.7\% compared to 4.1\%), as is employee ownership as a percent of pay (30.6\% compared to $21.2 \%$ ). The median stock option holding is $\$ 75,000$ (counting the estimated profit on both vested and unvested stock options if they were exercised on the day of the survey), representing $100 \%$ of annual pay and $29 \%$ of total wealth. These stakes should be large enough to detect effects on worker and firm outcomes, if such effects exist.

Participation by type of job and company

Where are shared capitalism plans most likely? Theory broadly suggests that they are most likely to be adopted in jobs and companies where performance is most sensitive to employee effort, or where the need for flexibility is greatest. Table 5 provides participation rates by basic job and company characteristics, using both the representative GSS dataset and our larger NBER dataset with more extensive measures.

The idea that shared capitalism is most likely in performance-sensitive jobs is supported by the finding that profit/gainsharing is most common among sales and management employees (48\% and 56\%, in col. 1), but the incidence remains substantial among all but service employees (19\%). Managers are also the most likely to own company stock (27\%, col. 2), but are not particularly more likely to hold stock options (14\%, col. 3). The NBER data show high levels of participation in profit/gainsharing and employee ownership for all occupational groups, and low levels of stock options only among production workers and service employees (since the NBER stock option companies had few production or service employees, although this is not true for all stock option firms in the U.S.). 
Those who have been at their jobs for less than one year are the least likely to participate in shared capitalism, partly reflecting probationary periods (e.g., employees only become eligible for an ESOP after 6 months or one year). The exception is that new employees are more likely than older employees to hold stock options in the NBER dataset, probably reflecting the use of stock options to lure workers into the jobs.

Not surprisingly, shared capitalism is more common among full-time employees in both the GSS and NBER data—such employees are more likely to be core employees whose commitment and effort are important to workplace performance. Also not surprisingly, union members are less likely than non-union employees to be part of profit/gainsharing plans (38\% vs. $14 \%$, in col. 1). Unions tend to resist profit sharing due to concerns that management can manipulate profit figures, and that such pay can create inequality among workers (Zalusky, 1990). It is striking, however, that union members in the GSS are actually slightly more likely than non-union employees to report owning company stock and holding stock options. While there have been some noteworthy examples of unions leading employee buyouts (which make up a very small percentage of firms with employee ownership), this employee ownership result more likely reflects the greater likelihood of retirement plans among union employees, many of which invest in company stock.

The free rider problem predicts that these plans will be most advantageous in small workplaces. Contrary to this prediction, larger establishments are more likely to have each of the types of shared capitalism (cols. 1-3). All three types of shared capitalism are most common in establishments with 1000 or more employees. These large establishment sizes strongly suggest that if these companies want to use shared capitalism to enhance performance, they need to take steps to counter the free rider problem. 
Finally, shared capitalism is well-represented in every broad industry. Profit/gainsharing is most common in manufacturing, finance, and computer services ( $>50 \%$ in each), while employee ownership and stock options are most common in transportation/ communications/ utilities, finance, and computer services. The figures are consistently highest in computer services, reflecting the strong use of these incentives in new economy companies that rely heavily on human skill and ingenuity (Blasi, Kruse, and Bernstein, 2003). This is not consistent with the notion that shared rewards (especially employee ownership) will only work with professional groups such as lawyers or more specialized service firms (Hansmann, 1996).

\section{Work organization and shared capitalism}

How are these jobs structured, and what policies accompany shared capitalism plans? Table 6 uses the GSS and NBER data to explore how shared capitalism relates to several aspects of work organization and policies, shedding some light on the role these plans may play in companies. The figures in Table 6 are simple cross-tabulations-these relationships are analyzed using probit regressions in Table 7.

Consistent with the idea that shared capitalism can encourage cooperative teamwork, profit/gainsharing employees are more likely to work in teams, to be able to observe co-worker performance, and to have low levels of supervision (cols. 2, 6). The patterns are mixed, however, for employee-owners and stock option holders. The stock option holders are more likely to work in teams and to have low levels of supervision, but are no more likely (and may be less likely) to easily observe co-worker performance (cols. 4, 8). This may have to do with their concentration in high tech and computer industry firms. Employee-owners are not more likely to work in teams or to find it easy to observe co-workers, although they are more likely to have low 
levels of supervision (cols. 3, 7). This suggests that profit/gainsharing may be the primary method for encouraging cooperative teamwork in day-to-day work, while employee ownership and stock options may affect other outcomes (e.g., identification, loyalty, turnover). This is a good example of how we can learn from the analysis of prevalence. It could possibly be the basis of an argument for combining short-term forms of shared capitalism like profit/gainsharing with longer horizon forms such as employee ownership and stock options. Whether these forms do have the effects suggested by the prevalence figures is the job of accompanying papers to sort out.

Participation in decisions may, as discussed earlier, be an important complement to shared capitalism programs in affecting workplace performance. Such participation can give employees the means to improve performance, while shared capitalism provides the incentives. The data in Table 6 generally support the idea of complementarity, with shared capitalism employees having higher levels on both the objective measure of participation (being in an employee involvement team) and the subjective measures (having say/influence in one's job, or participating with others in decisions affecting one's job). Profit/gainsharing is consistently linked to higher participation in both datasets, while employee ownership and stock option holding show mixed results in the GSS but strong associations with participation in the NBER data.

Training may be another important complementary policy, helping to develop worker skills and commitment that can be reinforced by shared capitalism. The GSS tabulations in Table 6 show that those with profit/gainsharing are more likely to report that they have the training opportunities they need. The shared capitalism employees in the NBER firms are more likely to have had employer-sponsored training in the past year, while profit/gainsharing 
employees and employee-owners — but not stock option holders-are slightly more likely to frequently participate in job rotation.

Finally, job security may be an important complementary policy_it is hard to maintain worker commitment and cooperative teamwork if employees are afraid they will be laid off. Just over $90 \%$ of the GSS shared capitalism employees report they are unlikely to be laid off, which is higher than the $88 \%$ figure for the entire sample, with significantly greater job security for profit/gainsharers and employee-owners. All three groups of shared capitalism employees report significantly greater job security in the NBER data. In addition, each of these three groups reports a higher expected likelihood of working at the company for a long time, and of seeing their current jobs as part of a long-term career.

Table 7 analyzes these relationships using probit regressions to predict the likelihood of participating in each of the types of shared capitalism. The NBER regressions control for company fixed effects, thereby doing within-company comparisons of who participates. Most of the simple relationships described above are maintained when controlling for other variables. In particular, each of the plans is associated with greater participation in decisions and with employer-sponsored training in the past year. The ease of observing co-workers is a significant predictor of profit/gainsharing in both the GSS and NBER data, suggesting an important role for peer pressure. Closeness of supervision is a strong negative predictor in the NBER sample, and high job security is a strong positive predictor, indicating that freedom from supervision and job security may be complementary policies. Finally, the GSS regressions confirm that each of the types of shared capitalism are more likely in larger establishments (though the highest prevalence of profit/gainsharing is among establishments with 100-999 employees rather than the $1000+$ group). 


\section{Risk aversion and shared capitalism}

Risk aversion is clearly an important consideration in shared capitalism. We measured risk aversion with several questions on the NBER company surveys, including a self-rating on a 0-10 scale, how much one would pay for a bet, whether one would take a job with stable pay versus one with risky but higher pay, and whether one regularly buys and sells stock on the stock market. These are strongly related and appear to measure a common risk propensity. Here we focus on the employee's self-rating, where 0 is "hate to take any kind of risk" and 10 is "love to take risks" (see question wording in appendix). The average score is 5.6, but there is wide dispersion: $20 \%$ of employees give scores of 3 or less, while, and $41 \%$ give themselves scores of 7 or more. Of course these employees are not representative of the overall workforce, since they have chosen to work in companies with shared capitalism and $85 \%$ are covered by some type of shared capitalism plan. We can nonetheless learn something about the role of risk aversion by examining its relation to plan participation and worker views of variable pay.

Risk aversion is related to plan participation, as shown in Table 8, but not always in expected ways. A surprising finding is that those who are eligible for profit sharing rate themselves as more risk averse (less risk loving) than those who are not eligible, both before and after controlling for demographic, pay, and wealth variables (cols. 3, 5). One explanation of this is that profit sharing may be less risky than sinking your savings in your company stock under certain circumstances, such as where you feel you are paid at the market rate for wages and there is no wage substitution. Eligibility for gainsharing and individual bonuses, in contrast, is associated with greater risk loving. Like profit sharers, stock option holders appear slightly more risk averse after controlling for demographic, pay, and wealth variables. 
Employee owners appear to like risk more on average, but this varies by type of employee ownership. Those owning stock through 401(k) plans or open market purchases are clearly more risk loving than others (Table 8, col. 6), undoubtedly reflecting the self-selection of risk lovers buying stock or allocating 401(k) accounts toward company stock. ESOP members, however, are more risk averse than non-ESOP members in a simple comparison, and risk loving is not a significant predictor of ESOP membership, or of owning stock through an ESPP or exercised stock options, after controlling for demographic, pay, and wealth variables.

Does risk aversion affect employees' views of variable pay? Most of the NBER workers would prefer to be paid in part with profit sharing, company stock, or stock options, as shown in Table 9. Remarkably, even two-thirds (66\%) of the most risk-averse employees would prefer this, while $86 \%$ of the least risk-averse prefer this. Very similar results are obtained by a question asking about the employee's next pay increase, where again two-thirds of the most riskaverse would prefer at least some of the increase in shared capitalism pay.

About three-fourths of employees would prefer a new bonus program to be based at least in part on their individual performance, where the line of sight is clearly greatest. Almost threefifths (58\%), however, prefer that it also be based on company profits or performance, while only about one-third (37\%) prefer that it be based in part on workgroup performance. It may be that the greater line of sight for workgroup bonuses is trumped by their greater perceived risk, as workgroup performance is probably seen as more variable than overall company performance (which averages across all workgroups in the company). Those with low risk aversion are more likely to choose individual- or workgroup-based bonuses, while risk aversion is not related to the desire for company-based bonuses.

Most employees would not vote to sell the company to an outside investor for a 50\% 
premium, but would do so for a $100 \%$ premium. This likelihood is lowest among those with high risk aversion, reflecting greater concern about job loss if the company were sold. While the concern about job loss is the most common reason for refusing to sell the company, about onethird of employees say they would refuse to sell because they like owning company stock (33\%), and a similar number say they would refuse because they like the sense of community from employee ownership (37\%). A lot more research is needed on this broader issue of employee ownership and workers' corporate governance rights since governance has always been seen by corporate finance experts as being partly about managing risk. (It is standard in investment banking to provide more governance rights when risk is higher.)

Finally, most workers say that they would be willing to accept some degree of lower regular pay in exchange for the opportunity to participate in a company-based bonus system averaging $10 \%$ of their pay. This willingness varies substantially, however: two-fifths (41\%) would not accept lower pay, while one-sixth (15\%) would accept less than 5\% lower pay, onefourth (27\%) would accept 5\% lower pay, and one-sixth (17\%) would accept more than 5\% lower pay. This is predictably related to risk aversion: a majority of the most risk averse would not accept any lower regular pay (55\%), compared to only a third of the least risk averse (33\%).

The NBER employees of course may not be representative of the overall workforce-in particular, they may have joined these companies because they are less risk averse and more favourably inclined toward shared capitalism than most workers. The data are broadly consistent, however, with existing representative surveys. Over half (57\%) of workers in a 1986 BNA/Bruskin poll said they would trade their next pay increase for a share in company, while 44\% said this in a 1989 EBRI/Gallup poll (summarized in Kruse and Blasi, 1999). Workers in general report that, if they had company stock, they would be less likely than the NBER workers 
to vote to sell the company even for a substantial premium. ${ }^{12}$ This indicates either a more rosy view of the advantages of employee ownership among the workforce in general, or more concern about an outside investor laying off workers. The public surveys do show positive views of employee ownership: strong majorities think employee-owners will work harder, have higher commitment, and be more concerned with the long-term success of the company. Participation in decisions, however, appears to be very important: most employees would prefer participation in decisions to having a share of ownership, and say that if they owned stock, they would not let management vote their shares on major corporate issues (summarized in Kruse and Blasi, 1999).

Overall, as expected, risk aversion is a key factor for shared capitalism: it appears most likely to steer workers away from positions providing gainsharing or individual bonuses, and to discourage workers from allocating $401(\mathrm{k})$ assets toward company stock or purchasing company stock on the open market. Greater risk aversion is associated with less positive views of shared capitalism pay, but even among the most risk-averse employees, two-thirds says they prefer some shared capitalism as part of their pay package.

\section{Conclusion}

Contrary to concerns about the free rider problem and worker risk aversion, a substantial number of workers participate in shared capitalism plans and are open to more shared capitalism in their firms. Nationally-representative surveys of private-sector employees and firms show that:

- $\quad$ One-fourth to one-third of employees are eligible for profit sharing

12 The $41 \%$ who would sell for a $50 \%$ premium is somewhat higher than the $23 \%$ figure for all employees from a $1989 \mathrm{EBRI} / \mathrm{Gallup}$ poll, and the $64 \%$ who would vote to sell for a $100 \%$ premium is much higher than the $36 \%$ figure for all employees from a 1994 EBRI/Gallup poll (summarized in Kruse and Blasi, 1999). 
- $\quad$ About one-fourth of employees are eligible for gainsharing

- $\quad$ About one-fifth of employees own stock in their companies

- Between one-twelfth and one-eighth of employees are eligible for stock options or hold stock options

- $\quad$ Overall, between one-third and one-half of employees participate in some form of shared capitalism

Why do firms use these plans, and why do workers accept them? This paper broadly reviews the major reasons for adopting these plans and some of the research results. The two major categories of reasons for adopting these plans are productivity-related and flexibilityrelated reasons. Prior studies find that these plans tend to be associated with better company performance on average, but there is wide dispersion in outcomes. The goal of accompanying papers using these data is to explain this dispersion and understand why, where, and how shared capitalism does or does not work. Limited evidence also shows that these plans tend to be associated with greater job stability, firm survival, and employee compensation—-the latter finding helping to explain why employees express positive attitudes toward shared capitalism plans.

The dispersion of results indicates that there is still much to learn about how these plans can play a positive role in workplaces. Research has not nailed down the complementary role that other human resource policies play in affecting worker attitudes and firm performance. To help address the variety of questions surrounding shared capitalism, this paper has introduced the NBER database of over 40,000 employee surveys in 14 firms with different combinations of profit sharing, gainsharing, employee ownership, and stock options. 
Both the NBER dataset and the nationally-representative GSS dataset indicate that while shared capitalism exists broadly throughout the economy, it is not distributed randomly across firms and employees. One important finding is that shared capitalism plans are more likely in larger establishments, where free riding is likely to be the highest. To counter free riding, firms may combine shared capitalism with other policies to create a cooperative culture. An initial exploration of work organization and policies supports this idea: shared capitalism employees are more likely to participate in workplace decision-making and training programs, and to have high job security and low levels of supervision. Within-company comparisons show that they are also more likely to work in teams, and profit/gainsharing employees can more easily observe co-worker performance, creating the conditions for cooperative teamwork. An examination of risk aversion in the NBER dataset shows that, as expected, risk aversion is linked to lower participation in several types of plans and less positive views of shared capitalism, but even among the most risk averse employees, two-thirds prefer to have some form of shared capitalism in their pay package.

So risk aversion does not appear to be an insurmountable barrier and there appear to be conditions for productive cooperation-does this in fact occur? What other effects does shared capitalism have on both firms and employees? These relationships are probed and tested in the accompanying papers, using the GSS and NBER data to explore a wide variety of outcomes for both workers and firms.

Over the last few decades many economists have said about various shared capitalism practices: "If it makes so much sense then why do we not observe more firms and employees doing it?” The response put forward by these prevalence figures is: "It appears to have spread throughout the economy, so what does that mean?” This paper has examined some of the 
linkages between shared capitalism practices and other employment practices. These linkages raise another series of questions: Are managers in companies making the right choices about how to achieve optimal performance from shared capitalist practices, or are there patterns and combinations that work better and worse? In other words, is what we observe optimal because that is the shared capitalist arrangement that has emerged in the laboratory of real life? Or, should managers consider making substantive changes to how they organize shared capitalism because it can be done well or poorly? One needs to beware of looking at these incidence patterns with a "deterministic" frame of mind. It should not be immediately concluded that just because there are certain types of shared capitalist practices (such as company stock in 401k plans as a lone form of shared capitalism) or combinations of these practices with human resource policies (such as a low incidence of self-directed work teams with employee ownership) that somehow managers have told us these are the best workable combinations. Firms and managers may have it wrong in some cases and right in others. These data will be used to explore the answers to these questions.

This NBER research program continues a long tradition of examination of shared capitalism by economists. The phenomenon was seen as being so important that John Bates Clark, a founder of the American Economic Association, wrote a book in the 1880's calling for the combination of profit-sharing and employee ownership in companies to improve business performance by motivating worker involvement (Clark, 1886). With his encouragement, the first volume of the journal of the American Economics Association included an article surveying shared capitalism in companies in the Northeast (Bemis, 1886) and in the Midwestern city of Minneapolis (Shaw, 1886). Given that almost half of U.S. employees currently report participating in some form of shared capitalism, it is time to take a closer look. 


\section{APPENDIX: GSS and NBER question wordings}

\section{COMPENSATION}

Profit sharing (GSS and NBER): "In your job are you eligible for any type of performance-based pay, such as individual or group bonuses, or any type of profitsharing? What does the size of these performance-based payments depend on? Company profits or performance" ( $0=$ no, $1=$ yes)

Profit sharing as \% of pay (GSS and NBER): If "yes" to profit sharing, answer to "What was the approximate total dollar value of the payment(s) you received [in the most recent year of bonuses]?" divided by basepay+overtime, otherwise 0 .

Gainsharing (GSS and NBER): "In your job are you eligible for any type of performance-based pay, such as individual or group bonuses, or any type of profitsharing? What does the size of these performance-based payments depend on? Workgroup or department performance" (0=no, $1=$ yes)

Gainsharing as \% of pay (GSS and NBER): If "yes" to gainsharing, answer to "What was the approximate total dollar value of the payment(s) you received [in the most recent year of bonuses]?" divided by basepay+overtime, otherwise 0 .

Individual bonus (GSS and NBER): "In your job are you eligible for any type of performance-based pay, such as individual or group bonuses, or any type of profitsharing? What does the size of these performance-based payments depend on? Individual performance" ( $0=$ no, $1=$ yes)

Individual bonus as \% of pay (GSS and NBER): If "yes" to individual bonus, answer to "What was the approximate total dollar value of the payment(s) you received [in the most recent year of bonuses]?" divided by basepay+overtime, otherwise 0 .

Own employer stock (GSS): "Do you own any shares of stock in the company where you now work, either directly or through some type of retirement or stock plan?" ( $0=$ no, $1=$ yes)

Employer stock as \% of pay (GSS): If "yes" to "hold employer stock," answer to "Please give a general estimate of how much cash you would get if all this stock were sold today?" divided by annual earnings, otherwise 0

Own employer stock (NBER): Any employer stock held through ESOP, Employee Stock Purchase Plan, 401(k), exercised stock options, or open market purchases $(0=$ no, 1=yes)

Employer stock as \% of pay (NBER): If "yes" to "Hold employer stock," the sum of answers to questions about value of stock held in different plans, divided by 
basepay+overtime, otherwise 0

Hold stock options (GSS and NBER): "Do you currently hold any stock options in your company (vested or unvested)?" ( $0=$ no, $1=$ yes)

Stock options as \% of pay (NBER): If "yes" to "Hold stock options," the sum of answers to questions about value of vested and unvested stock, divided by basepay+overtime, otherwise 0

\section{WORK ORGANIZATION}

Work as part of team (GSS and NBER): "In your job, do you normally work as part of a team or group, or do you work mostly on your own?"

Ease of observing co-worker performance (GSS and NBER): "In your job how easy is it for you to see whether your co-workers are working well or poorly? Please rate on a scale of 0 to 10 , where 0 equals not at all easy, and 10 equals very easy."

Closeness of supervision (NBER): "Are you closely supervised, or do you work fairly independently of close supervision?" (0-10 scale, $0=$ closely supervised, $10=$ independent of close supervision)

In EI team (NBER): " Some companies have organized workplace decision-making in ways to get more employee input and involvement. Are you personally involved in any team, committee or task force that addresses issues such as product quality, cost cutting, productivity, health and safety, or other workplace issues?" ( $0=$ no, $1=y e s)$

Lot of influence in job decisions (NBER): "How much involvement and direct influence do YOU have in: Deciding HOW to do your job and organize the work" (coded 1 if worker responded $4=$ "a lot" on 1-4 scale, and 0 otherwise)

Lot of influence in setting dept. goals (NBER): "How much involvement and direct influence do YOU have in: Setting GOALS for your work group or department" (coded 1 if worker responded 4="a lot" on 1-4 scale, and 0 otherwise)

Lot of influence in company decisions (NBER): "How much involvement and direct influence do YOU have in: Overall company decisions" (coded 1 is worker responded 4="a lot" on 1-4 scale, and 0 otherwise)

Lot of say on job (GSS): "I have a lot of say about what happens on my job" (coded 1 if worker responded "strongly agree" on 1-4 scale, and 0 otherwise)

Often make decisions with others (GSS): "In your job, how often do you take part with others in making decisions that affect you?" (coded 1 if worker responded "often" on 1-4 scale, and 0 otherwise) 
Often help set way things done on job (GSS): "How often do you participate with others in helping set the way things are done on your job?" (coded 1 if worker responded "often" on 1-4 scale, and 0 otherwise)

Participation index (GSS): Average of above three items (alpha=.737)

Have training opportunities I need (GSS): "I have the training opportunities I need to perform my job safely and competently" (coded 1 if worker responded "very true" on 1-4 scale, and 0 otherwise)

Formal training (NBER): "In the last 12 months have you received any formal training from your current employer, such as in classes or seminars sponsored by the employer?" (0=no, $1=$ yes $)$

Frequently participate in job rotation (NBER): "How frequently do you participate in a job rotation or cross-training program where you work or are trained on a job with different duties than your regular job?" (coded 1 if worker responded "frequently", and 0 otherwise)

High job security (GSS and NBER): "Thinking about the next twelve months, how likely do you think it is that you will lose your job or be laid off?" (coded 1 if "not at all likely" or "not very likely", and 0 otherwise)

See myself working here a long time (NBER): "Which ONE of the following statements best describes how you think of your current employer? 1=I see myself working here for the foreseeable future (a long time), $0=$ I do not see myself working here very long."

Current job is part of long-time career (NBER): "Thinking about your current job (rather than your employer), do you look upon it as part of your long term career, or a position that is not part of your long term career?" (1=yes, $0=$ no)

\section{RISK AVERSION AND PREFERENCES OVER PAY}

Risk loving (NBER): "Some people like to take risks and others dislike taking risks. Where would you place yourself on a scale of how much you like or dislike taking risks, where 0 is hating to take any kind of risk and 10 is loving to take risks?"

Risk aversion (NBER): High risk aversion $=0$ to 3 on risk loving scale, medium risk aversion $=4$ to 6 on risk loving scale, and low risk aversion $=7$ to 10 on risk loving scale.

Type of pay preferred (NBER): "If it was your choice and yours alone, would you prefer that you be paid: $0=$ All fixed wage or salary, with no profit-sharing, company 
stock, or stock options; $1=$ Paid in part with a variable amount dependent on company performance, through profit-sharing, company stock, or stock options"

Preference for new bonus plan (NBER): If your employer announced a new compensation plan that would give up to $10 \%$ of pay in the form of bonuses, would you like this pay to be based on (mark all that apply): Your individual performance, Your workgroup performance, Company profits or performance"

Would vote to sell company (NBER): "If you owned stock in a company where you worked and an outside investor offered to buy the company for 50\% more than the market value of the stock, would you vote to sell the company?"

Lower pay accepted for company-based bonus (NBER): "Imagine that you work for a company that offers you the opportunity to participate in a bonus program. Over time, the bonus will pay you on average $10 \%$ of your regular pay, but it could be higher or lower in any given year depending on the company's performance that year. How much less regular pay would you be willing to accept in order to get the possible performance bonus?"

Preference for next pay increase (NBER): "For your next pay increase, would you prefer that it come in the form of: 1=All fixed wages, with no profit sharing, company stock, or stock options, 2=Split between fixed wages and profit sharing, company stock, or stock options, $3=$ All in the form of profit sharing, company stock, or stock options" 


\section{References}

Alchian, Armen A., and Harold Demsetz. 1972. "Production, Information Costs, and Economic Organization," American Economic Review, 62, pp. 777-795.

Askwith, M.E. 1926. Profit-Sharing: An Aid to Trade Revival. London: Duncan Scott.

Bartel, Ann, Richard Freeman, Casey Ichniowski, and Morris Kleiner. 2003. "Can a Work Organization Have an Attitude Problem? The Impact of Workplaces on Employee Attitudes and Economic Outcomes," National Bureau of Economic Research Working Paper 9987.

Beatty, Anne. 1994. "An Empirical Analysis if the Corporate Control, Tax and Incentive Motivations for Adopting Leveraged Employee Stock ownership Plans," Managerial and Decision Economics, 15(4), pp. 299-315.

Bemis, Edward W. 1886. "Cooperation in the Northeast,” Publications of the American Economic Association 1(5) (November), pp. 7-136.

Blair, Margaret, Douglas Kruse, and Joseph Blasi. 2000. “Is Employee Ownership an Unstable Form? Or a Stabilizing Force? in Thomas Kochan and Margaret Blair, eds., The New Relationship: Human Capital in the American Corporation. Washington, D.C.: The Brookings Institution.

Blasi, Joseph, Michael Conte and Douglas Kruse. 1996. "Employee Ownership and Corporate Performance Among Public Corporations," Industrial and Labor Relations Review, Vol. 50, No. 1, October, pp. 60-79.

Blasi, Joseph, Richard Freeman, Chris Mackin, and Douglas Kruse. 2008. "Creating a Bigger Pie? The Effects of Employee Ownership, Profit Sharing, and Stock Options on Workplace Performance." Presented at NBER/Russell Sage Foundation conference, New York, NY, October 2006.

Blasi, Joseph, Maya Kroumova and Douglas Kruse. 1997. Kremlin Capitalism: Privatizing The Russian Economy. Ithaca: Cornell University Press.

Blasi, Joseph and Douglas Kruse. 1991. The New Owners: The Mass Emergence of Employee

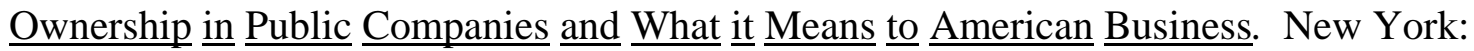
HarperBusiness.

-----. 2006. “High Performance Work Practices at Century’s End,” Industrial Relations, Vol. 45, No. 4 (October), pp. 547-578.

-----, and Aaron Bernstein. 2003. In the Company of Owners: The Truth About Stock Options 
(And Why Every Employee Should Have Them). New York: Basic Books, 2003.

Blasi, Joseph, Douglas Kruse, and Harry M. Markowitz. 2008. “Risk and Lack of Diversification under Employee Ownership and Shared Capitalism. ” Presented at NBER/Russell Sage Foundation conference, New York, NY, October 2006.

Bonin, John P., and Louis Putterman. 1987. Economics of Cooperation and the Labor-managed Economy. Chur, Switzerland: Harwood Academic Publishers.

Boning, Brent, Casey Ichniowski, and Kathryn Shaw. 2001. "Opportunity Counts: Teams and the Effectiveness of Production Incentives," National Bureau of Economic Research Working Paper 8306.

BLS. 2005. National Compensation Survey: Employee Benefits in Private Industry in the United States, 2003. Bulletin 2577, U.S. Bureau of Labor Statistics, October.

-----. 2006. "National Compensation Survey: Employee Benefits in Private Industry in the United States, March 2006," Summary 06-05, U.S. Bureau of Labor Statistics, August.

-----. 2007. National Compensation Survey: Employee Benefits in Private Industry in the United States, 2005. Bulletin 2589, U.S. Bureau of Labor Statistics, May.

-----. 2008. “National Compensation Survey: Employee Benefits in Private Industry in the United States, March 2007,” Summary 07-05, U.S. Bureau of Labor Statistics, August.

Brown, Jeffrey, Nellie Liang, and Scott Weisbenner. 2004. "401(k) Matching Contributions in Company Stock: Costs and Benefits for Firms and Workers," NBER Working Paper 10419, August.

Buchele, Robert, Douglas Kruse, Loren Rodgers, and Adria Scharf. 2008. "Show Me the Money: The Wealth Impact of Shared Capitalism.” Presented at NBER/Russell Sage Foundation conference, New York, NY, October 2006.

Budd, John. 2008. "Does Employee Ignorance Undermine Shared Capitalism” Presented at NBER/Russell Sage Foundation conference, New York, NY, October 2006.

Bullock, R.J. and Mark E. Tubbs. 1990. "A Case Meta-Analysis of Gainsharing Plans as Organization Development Interventions," Journal of Applied Behavioral Science, 26, 3, pp. 383-404.

Carberry, Edward. 2008. “An Analysis of Social Stratification in Companies with Shared Capitalism.” Presented at NBER/Russell Sage Foundation conference, New York, NY, October 2006.

Clark, John Bates. 1886. The Philosophy of Wealth. Boston: Ginn \& Company. 
Collins, Denis. 1998. Gainsharing and Power: Lessons from Six Scanlon Plans. Ithaca and London: Cornell University Press, ILR Press.

Craig B. and J. Pencavel. 1992. "The Behavior of Worker Cooperatives: The Plywood Companies of The Pacific Northwest," American Economic Review, 82, 1083-1105.

-----. 1993. "The Objectives of Worker Cooperatives," Journal of Comparative Economics, Vol. 17(2), June, pp. 288-308.

Del Boca, Alessandra, Douglas Kruse, and Andrew Pendleton. 1999. "Decentralisation of Bargaining Systems and Financial Participation: A Comparative Analysis of Italy, UK and the US," Lavoro e Relazioni Industriali, Summer 1999.

Dow, Gregory. 2003. Governing the Firm: Workers' Control in Theory and Practice. Cambridge, England: Cambridge University Press.

EBRI/Gallup. 1994. "Public Attitudes on Employee Stock Ownership and Benefit Promises, 1994,” EBRI/Gallup Poll \#G-54, Employee Benefit Research Institute, Washington, D.C.

European Foundation for the Improvement of Living and Working Conditions. 1997. New Forms of Work Organization: Can Europe Realize Its Potential? Luxembourg: Office for Official Publications of the European Communities, 1997.

Fitzroy, Felix, and Kornelius Kraft. 1995. "On the Choice of Incentive in Firms," Journal of Economic Behavior and Organization, 26, pp. 145-160.

Freeman, Richard, and Morris Kleiner. 1990. "The Impact of New Unionization on Wages and Working Conditions," Journal of Labor Economics, 8:1, S8-S25.

Freeman, Richard, and Joel Rogers. 1999. What Workers Want. New York: Russell Sage and Cornell University Press.

Freeman, Richard, Douglas Kruse, and Joseph Blasi. 2008. “Worker Responses to Shirking under Shared Capitalism.” Presented at NBER/Russell Sage Foundation conference, New York, NY, October 2006.

Gregg, P.A. and Machin, S.J. 1988. "Unions and the Incidence of Performance Linked Pay Schemes in Britain," International Journal of Industrial Organization, 6, 91-107.

Harden, Erika, Douglas Kruse, and Joseph Blasi. 2008. "Who Has a Better Idea: Innovation, Shared Capitalism, and Human Resource Policies.” Presented at NBER/Russell Sage Foundation conference, New York, NY, October 2006.

Hansmann, Henry. 1996. The Ownership of Enterprise. Cambridge: Harvard University Prress. 
Ichniowski, Casey, and Kathryn Shaw. 1995. "Old Dogs and New Tricks: Determinants of the Adoption of Productivity-Enhancing Work Practices," Brookings Papers on Economic Activity, Microeconomics 1995, pp. 1-55.

Ichniowski, Casey, Thomas Kochan, David Levine, Craig Olson, and George Strauss. 1996. "What Works at Work: Overview and Assessment," Industrial Relations, 35(3) 299-333.

Ichniowski, Casey, Kathryn Shaw, and Giovanna Prennushi. 1997. "The Effects of Human Resource Management Practices on Productivity: A Study of Steel Finishing Lines," American Economic Review, 87 (3), pp. 291-313.

Jones, Derek C; Kato, Takao. 1995. "The Productivity Effects of Employee Stock-Ownership Plans and Bonuses: Evidence from Japanese Panel Data," American Economic Review, Vol. 85 (3), pp. 391-414.

Kardas, Peter; Adria L. Scharf; and Jim Keogh. 1998. "Wealth and Income Consequences of ESOPs and Employee Ownership: A Comparative Study from Washington State," Journal of Employee Ownership Law and Finance. Vol. 10, No. 4, Fall.

Kato, Takao; Lee, Ju Ho; Lee, Kang-Sung; Ryu, Jang-Soo. 2005. "Employee Participation and Involvement in Korea: Evidence from a New Survey and Field Research," International Economic Journal, Vol. 19 (2), June, pp. 251-81.

Kruse, Douglas. 1993. Profit Sharing: Does It Make a Difference? Kalamazoo, MI: W.E. Upjohn Institute for Employment Research.

-----. 1996. “Why Do Firms Adopt Profit-Sharing and Employee Ownership Plans?” British Journal of Industrial Relations, Vol. 34, No. 4 (December), pp. 515-38.

-----. 1998. “Profit Sharing and the Demand for Low-Skill Workers,” in Richard Freeman and Peter Gottschalk, eds., Generating Jobs: Increasing the Demand for Low-Skill Workers. New York: Russell Sage Foundation, pp. 105-153.

-----. 2002. “Research Evidence on Prevalence and Effects of Employee Ownership,” Testimony before the Subcommittee on Employer-Employee Relations, Committee on Education and the Workforce, U.S. House of Representatives, February 13, 2002.

-----, and Joseph R. Blasi. 1997. "Employee Ownership, Employee Attitudes, and Firm Performance: A Review of the Evidence,” in David Lewin, Daniel J.B. Mitchell, and Mahmood A. Zaidi, eds., The Human Resource Management Handbook, Part I. Greenwich, Connecticut and London, England: JAI Press Inc.

-----. 1999. “Public Opinion Polls on Employee Ownership and Profit Sharing,” Journal of Employee Ownership Law and Finance, Vol. 11, No. 3, Summer 1999, pp. 3-25. 
Kruse, Douglas, Richard Freeman, and Joseph Blasi. 2008. “Do Workers Gain by Sharing? Employee Outcomes Under Employee Ownership, Profit Sharing, and Broad-based Stock Options” Presented at NBER/Russell Sage Foundation conference, New York, NY, October 2006.

Lawler, Edward, Susan Mohrman, and G.E. Ledford. 1995. Creating High Performance Organizations: Practices and Results of Employee Involvement and Quality Management in Fortune 1000 Companies. San Francisco: Jossey-Bass.

Oyer, Paul, and Scott Schaefer. 2005. "Why Do some Firms Give Stock Options to All Employees? An Empirical Examination of Alternative Theories," Journal of Financial Economics, 76, pp. 99-133.

Park, Rhokeun., Douglas Kruse, and James Sesil. 2004. “Does Employee Ownership Enhance Firm Survival?” in Virginie Perotin and Andrew Robinson, eds., Advances in the Economic Analysis of Participatory and Labor-Managed Firms, Vol. 8. New York: Elsevier Science, JAI, pp. 3-33.

Pendleton, Andrew; Poutsma, Erik; Van Ommeren, Jos; Brewster, Chris. 2003. "The Incidence and Determinants of Employee Share Ownership and Profit Sharing in Europe," in Takao Kato and Jeffrey Pliskin, eds., Advances in the Economic Analysis of Participatory and Labor-Managed Firms, vol. 7. New York: Elsevier Science, JAI, pp. 141-72.

Poole, Michael. 1989. The Origins of Economic Democracy: Profit-Sharing and EmployeeShareholding Schemes. London: Routledge.

Poutsma, Erik. 1999. Financial Employee Participation in Europe. Nijmegen, Netherlands: Nijmegen University Business School, Report to the European Foundation for the Improvement of Living and Working Conditions.

Putterman, Louis, and Gil Skillman, Jr. 1988. "The Incentive Effects of Monitoring Under Alternative Compensation Schemes," International Journal of Industrial Organization, 6, pp. 109-119.

Scharf, Adria, and Christopher Mackin. 2000. "Census of Massachusetts Companies with Employee Stock Ownership Plans (ESOPs)." Boston: Commonwealth Corporation.

Shaw, Albert. 1886. "Cooperation in a Western City," Publications of the American Economic Association 1(4), September, pp. 7-106.

Smith, Stephen, Beom-Cheol Cin, and Milan Vodopivec. 1997. "Privatization Incidence, Ownership Forms, and Firm Performance: Evidence from Slovenia," Journal of Comparative Economics, Vol. 25(2), October, pp. 158-179.

Summers, Lawrence. 1986. "On the Share Economy," Challenge, November/December, pp. 47- 
50.

Tseo, George. 1996. "Chinese Economic Restructuring: Enterprise Development through Employee Ownership," Economic and Industrial Democracy, 17(2), May, pp. 243-279.

U.S. GAO. 1986. "Employee Stock Ownership Plans: Benefits and Costs of ESOP Tax Incentives for Broadening Stock Ownership.” GAO/PEMD-87-8. Washington, DC: General Accounting Office.

U.S. Senate, Subcommittee of the Committee on Finance. 1939. "Survey of Experiences in Profit Sharing and Possibilities of Incentive Taxation." Washington, D.C.: Government Printing Office.

Uvalic, M., and Daniel Vaughan-Whitehead, eds. 1997. Privatization Surprises in Transition Economies: Employee-ownership in Central and Eastern Europe. Cheltenham, UK and Lyme, NH: Elgar, distributed by American International Distribution Corp., Williston, VT.

Weitzman, Martin L. 1984. The Share Economy. Cambridge, MA: Harvard University Press.

-----. 1986. "Macroeconomic Implications of Profit Sharing," NBER Macroeconomics Annual 1986. Cambridge, MA: MIT Press, pp. 291-335.

-----, and Douglas Kruse. 1990. "Profit Sharing and Productivity," in Alan Blinder, ed., Paying For Productivity: A Look at the Evidence. Washington, D.C.: Brookings Institution.

Zalusky, John. 1990. "Labor-Management Relations: Unions View Profit Sharing," in Myron J. Roomkin, ed., Profit Sharing and Gain Sharing. Metuchen, NJ: Scarecrow Press, 65-78. 
Table 1 - Current Prevalence of Shared Capitalism Plans

\begin{tabular}{|c|c|c|c|}
\hline $\begin{array}{r}\text { Source: } \\
\text { Year: } \\
\text { Type of data: }\end{array}$ & $\begin{array}{c}\text { GSS } \\
2002 \\
\text { Employee } \\
\text { survey } \\
(1) \\
\end{array}$ & $\begin{array}{c}\text { GSS } \\
2006 \\
\text { Employee } \\
\text { survey } \\
(2) \\
\end{array}$ & $\begin{array}{c}\text { NOS } \\
2002 \\
\text { Firm } \\
\text { survey } \\
(3) \\
\end{array}$ \\
\hline \multicolumn{4}{|l|}{ PROFIT SHARING } \\
\hline \multicolumn{4}{|l|}{ Percent of employees covered } \\
\hline Eligible for bonuses based on company performance & $34 \%$ & $38 \%$ & $46 \%$ \\
\hline Received bonus last year based on company performance & $24 \%$ & $30 \%$ & \\
\hline \multicolumn{4}{|l|}{ Percent of firms with plans } \\
\hline $\begin{array}{l}\text { Any employees eligible for bonuses based on } \\
\text { company performance }\end{array}$ & & & $62 \%$ \\
\hline \multicolumn{4}{|l|}{ GAINSHARING } \\
\hline \multicolumn{4}{|l|}{ Percent of employees covered } \\
\hline Eligible for bonuses based on department or team performance & $23 \%$ & $27 \%$ & $23 \%$ \\
\hline Received bonus last year based on department or team performance & $17 \%$ & $21 \%$ & \\
\hline \multicolumn{4}{|l|}{ Percent of firms with plans } \\
\hline Any employees eligible for bonuses based on department or team performance & & & $35 \%$ \\
\hline \multicolumn{4}{|l|}{ EMPLOYEE OWNERSHIP } \\
\hline Own company stock & $21 \%$ & $18 \%$ & $16 \%$ \\
\hline \multicolumn{4}{|l|}{ Percent of firms } \\
\hline Any employees own company stock & & & $33 \%$ \\
\hline STOCK OPTIONS & $13 \%$ & & \\
\hline \multicolumn{4}{|l|}{ Percent of employees covered } \\
\hline Hold stock options & & $9 \%$ & \\
\hline Granted stock options last year & & $5 \%$ & \\
\hline \multicolumn{4}{|l|}{ Percent of firms } \\
\hline Any employees granted stock options last year & & & $14 \%$ \\
\hline \multicolumn{4}{|l|}{ COMBINATIONS } \\
\hline Any of above & $43 \%$ & $47 \%$ & \\
\hline \multicolumn{4}{|l|}{ Just one form: } \\
\hline Rec'd profit- or gainsharing bonus last year & $14.6 \%$ & $21.2 \%$ & \\
\hline Hold company stock & $5.0 \%$ & $3.8 \%$ & \\
\hline Hold stock options & $0.7 \%$ & $0.7 \%$ & \\
\hline \multicolumn{4}{|l|}{ Two forms: } \\
\hline Hold co. stock and rec'd profit- or gainsharing bonus last year & $3.7 \%$ & $5.3 \%$ & \\
\hline Hold co. stock and stock options & $6.1 \%$ & $3.2 \%$ & \\
\hline Hold stock options and rec'd profit- or gainsharing bonus last year & $0.4 \%$ & $0.6 \%$ & \\
\hline All three forms & $6.1 \%$ & $4.6 \%$ & \\
\hline Sample size & 1257 & 1173 & 312 \\
\hline
\end{tabular}


Table 2: Current Prevalence of Employee Participation in Decisions

\begin{tabular}{|c|c|c|c|}
\hline $\begin{array}{r}\text { Source: } \\
\text { Year: } \\
\text { Type of data: }\end{array}$ & \begin{tabular}{|c|} 
GSS \\
2002 \\
Employee \\
survey \\
$(1)$
\end{tabular} & $\begin{array}{c}\text { GSS } \\
2006 \\
\text { Employee } \\
\text { survey } \\
(2)\end{array}$ & $\begin{array}{c}\text { NOS } \\
2002 \\
\text { Firm } \\
\text { survey } \\
(3)\end{array}$ \\
\hline \multicolumn{4}{|l|}{ Percentage of employees covered } \\
\hline Self-directed team & & $30 \%$ & $17 \%$ \\
\hline Quality circles or employee involvement committees & & $33 \%$ & $17 \%$ \\
\hline $\begin{array}{l}\text { Often participate with others in making } \\
\text { decisions that affect job }\end{array}$ & $42 \%$ & $38 \%$ & \\
\hline $\begin{array}{l}\text { Often participate with others in helping } \\
\text { set how things are done on job }\end{array}$ & $45 \%$ & $42 \%$ & \\
\hline \multicolumn{4}{|l|}{ Percentage of firms with plans } \\
\hline Self-managed teams for non-managers & & & $39 \%$ \\
\hline Quality circles or employee involvement committees & & & $42 \%$ \\
\hline Worker safety committees & & & $49 \%$ \\
\hline Sample size & 1257 & 1173 & 312 \\
\hline
\end{tabular}

GSS=General Social Survey (from National Opinion Research Center, analyzed by authors)(all private sector) NOS=National Organizations Survey (from National Opinion Research Center, analyzed by authors)(all private sector) 
Table 3: NBER Survey Companies

\begin{tabular}{|c|c|c|c|}
\hline & $\begin{array}{l}\text { Broad-based } \\
\text { profit } \\
\text { sharing }\end{array}$ & $\begin{array}{l}\text { Broad-based } \\
\text { employee } \\
\text { ownership }\end{array}$ & $\begin{array}{l}\text { Broad-based } \\
\text { stock } \\
\text { options }\end{array}$ \\
\hline \multicolumn{4}{|l|}{$\begin{array}{l}\text { Manufacturing } \\
<1000 \text { employees }\end{array}$} \\
\hline Company 1 & Yes & ESOP & No \\
\hline Company 2 & Yes & ESOP & No \\
\hline Company 3 & Yes & ESOP & No \\
\hline Company 4 & Yes & ESOP and ESPP & Yes \\
\hline 1,000-9,999 employees & Yes & ESOP & No \\
\hline Company 6 & Yes & 401(k) ESOP & No \\
\hline Company 7 & Yes & ESOP & No \\
\hline $10,000+$ employees & & & \\
\hline $\begin{array}{ll} & \text { Company } 8 \\
\text { Servicelfinancial } & \end{array}$ & Yes & 401(k) w/co. stock & No \\
\hline$<1000$ employees & & & \\
\hline $\begin{array}{l}\text { Company } 9 \\
1,000-9,999 \text { employees }\end{array}$ & No & ESOP & No \\
\hline Company 10 & No & ESOP & No \\
\hline $\begin{array}{l}\text { Company } 11 \\
10,000+\text { employees }\end{array}$ & No & ESPP and $401(k)$ w/co. stock & Yes \\
\hline Hi-tech/Internet Company 12 & Yes & ESPP and $401(k)$ w/co. stock & Yes \\
\hline $\begin{array}{l}<1000 \text { employees } \\
\text { Company } 13 \\
10,000+\text { employees }\end{array}$ & Yes & ESPP & Yes \\
\hline Company 14 & Yes & ESPP & Yes \\
\hline Total companies with plans & 11 & 14 & 5 \\
\hline
\end{tabular}


TABLE 4: Shared capitalism types and intensities in GSS and NBER datasets

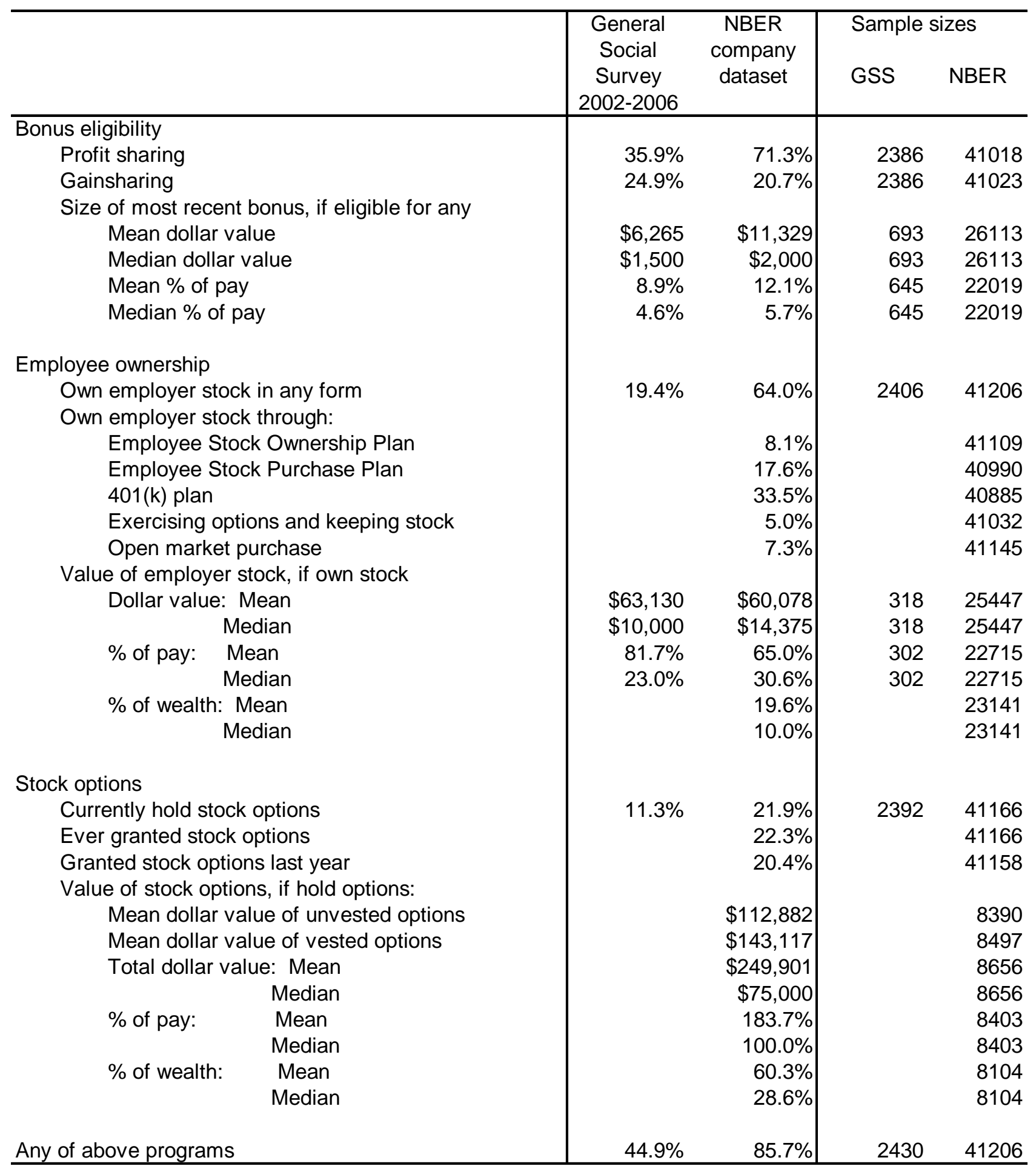


Table 5: Participation in Shared Capitalism by Job and Company Characteristics

\begin{tabular}{|c|c|c|c|c|c|c|c|c|}
\hline & \multicolumn{3}{|c|}{$\begin{array}{c}\text { GSS, 2002-2006 } \\
\text { Percent of those at left who: }\end{array}$} & \multicolumn{3}{|c|}{$\begin{array}{c}\text { NBER } \\
\text { Percent of those at left who: }\end{array}$} & \multicolumn{2}{|c|}{ Sample sizes } \\
\hline & $\begin{array}{l}\text { Are eligible for } \\
\text { profit- or } \\
\text { gainsharing } \\
\text { (1) }\end{array}$ & $\begin{array}{l}\text { Own } \\
\text { co. } \\
\text { stock } \\
(2)\end{array}$ & $\begin{array}{c}\text { Hold } \\
\text { stock } \\
\text { options } \\
(3) \\
\end{array}$ & $\begin{array}{c}\text { Are eligible for } \\
\text { profit- or } \\
\text { gainsharing } \\
(4)\end{array}$ & $\begin{array}{l}\text { Own } \\
\text { co. } \\
\text { stock } \\
(5) \\
\end{array}$ & $\begin{array}{c}\text { Hold } \\
\text { stock } \\
\text { options } \\
(6) \\
\end{array}$ & $\begin{array}{l}\text { GSS } \\
(7)\end{array}$ & $\begin{array}{c}\text { NBER } \\
(8)\end{array}$ \\
\hline Overall & $37.2 \%$ & $19.4 \%$ & $11.3 \%$ & $76.4 \%$ & $64.0 \%$ & $21.9 \%$ & 2,430 & 41,206 \\
\hline Occupation & & & & & & & & \\
\hline Production & $32.8 \%$ & $17.2 \%$ & $9.2 \%$ & $72.1 \%$ & $51.6 \%$ & $1.8 \%$ & 638 & 18,227 \\
\hline Admin. support & $35.8 \%$ & $23.5 \%$ & $15.5 \%$ & $68.5 \%$ & $63.8 \%$ & $18.1 \%$ & 340 & 2,246 \\
\hline Professional/technical & $36.7 \%$ & $21.9 \%$ & $13.7 \%$ & $82.9 \%$ & $78.8 \%$ & $44.1 \%$ & 443 & 11,582 \\
\hline Sales & $47.6 \%$ & $21.5 \%$ & $12.9 \%$ & $64.8 \%$ & $75.7 \%$ & $49.6 \%$ & 299 & 2,220 \\
\hline Service & $19.2 \%$ & $6.5 \%$ & $4.1 \%$ & $71.4 \%$ & $50.8 \%$ & $0.0 \%$ & 322 & 1,105 \\
\hline Management & $55.8 \%$ & $26.5 \%$ & $13.6 \%$ & $90.6 \%$ & $78.6 \%$ & $42.3 \%$ & 368 & 4,836 \\
\hline Lower mgt. & & & & $88.4 \%$ & $83.7 \%$ & $60.3 \%$ & & 4,214 \\
\hline Middle mgt. & & & & $88.9 \%$ & $79.4 \%$ & $48.3 \%$ & & 2,946 \\
\hline Upper mgt. & & & & $90.4 \%$ & $74.4 \%$ & $46.8 \%$ & & 856 \\
\hline \multicolumn{9}{|l|}{ Tenure } \\
\hline 1 year or less & $30.5 \%$ & $7.5 \%$ & $4.4 \%$ & $62.3 \%$ & $51.2 \%$ & $33.1 \%$ & 775 & 6,029 \\
\hline$>1,<=5$ years & $39.7 \%$ & $20.3 \%$ & $11.6 \%$ & $75.2 \%$ & $61.1 \%$ & $24.5 \%$ & 828 & 10,602 \\
\hline More than 5 years & $41.8 \%$ & $30.3 \%$ & $17.8 \%$ & $80.8 \%$ & $69.1 \%$ & $18.2 \%$ & 805 & 23,639 \\
\hline \multicolumn{9}{|l|}{ Hours of work } \\
\hline Part-time $(<35)$ & $20.7 \%$ & $8.2 \%$ & $4.9 \%$ & $54.8 \%$ & $45.9 \%$ & $13.1 \%$ & 447 & 588 \\
\hline Full-time (35+) & $40.9 \%$ & $22.0 \%$ & $12.7 \%$ & $76.7 \%$ & $64.2 \%$ & $21.6 \%$ & 1,983 & 39,625 \\
\hline \multicolumn{9}{|l|}{ Union member } \\
\hline No & $38.0 \%$ & $19.0 \%$ & $10.9 \%$ & $80.9 \%$ & $70.3 \%$ & $25.2 \%$ & 1,455 & 35,547 \\
\hline Yes & $14.0 \%$ & $24.2 \%$ & $12.4 \%$ & $46.7 \%$ & $22.4 \%$ & $0.7 \%$ & 161 & 5,001 \\
\hline \multicolumn{9}{|l|}{ Establishment size } \\
\hline 1 to 9 & $26.0 \%$ & $8.9 \%$ & $4.2 \%$ & & & & 505 & \\
\hline 10 to 49 & $35.6 \%$ & $12.3 \%$ & $7.1 \%$ & & & & 604 & \\
\hline 50 to 99 & $40.5 \%$ & $20.3 \%$ & $13.8 \%$ & & & & 329 & \\
\hline 100 to 999 & $44.1 \%$ & $26.9 \%$ & $16.0 \%$ & & & & 656 & \\
\hline $1000+$ & $44.8 \%$ & $36.8 \%$ & $20.1 \%$ & & & & 300 & \\
\hline \multicolumn{9}{|l|}{ Industry } \\
\hline Ag./mining/constr. & $22.3 \%$ & $11.1 \%$ & $5.2 \%$ & & & & 183 & \\
\hline Manufacturing & $52.0 \%$ & $29.1 \%$ & $18.3 \%$ & & & & 399 & \\
\hline Trans./comms./utilities & $43.8 \%$ & $37.9 \%$ & $23.7 \%$ & & & & 214 & \\
\hline Wholesale/retail & $32.7 \%$ & $14.0 \%$ & $8.3 \%$ & & & & 553 & \\
\hline Finance/insurance & $55.0 \%$ & $35.5 \%$ & $18.8 \%$ & & & & 198 & \\
\hline Computer services & $65.2 \%$ & $43.4 \%$ & $40.3 \%$ & & & & 52 & \\
\hline Other services & $28.6 \%$ & $9.9 \%$ & $4.0 \%$ & & & & 771 & \\
\hline
\end{tabular}


Table 6: Work Organization by Type of Shared Capitalism

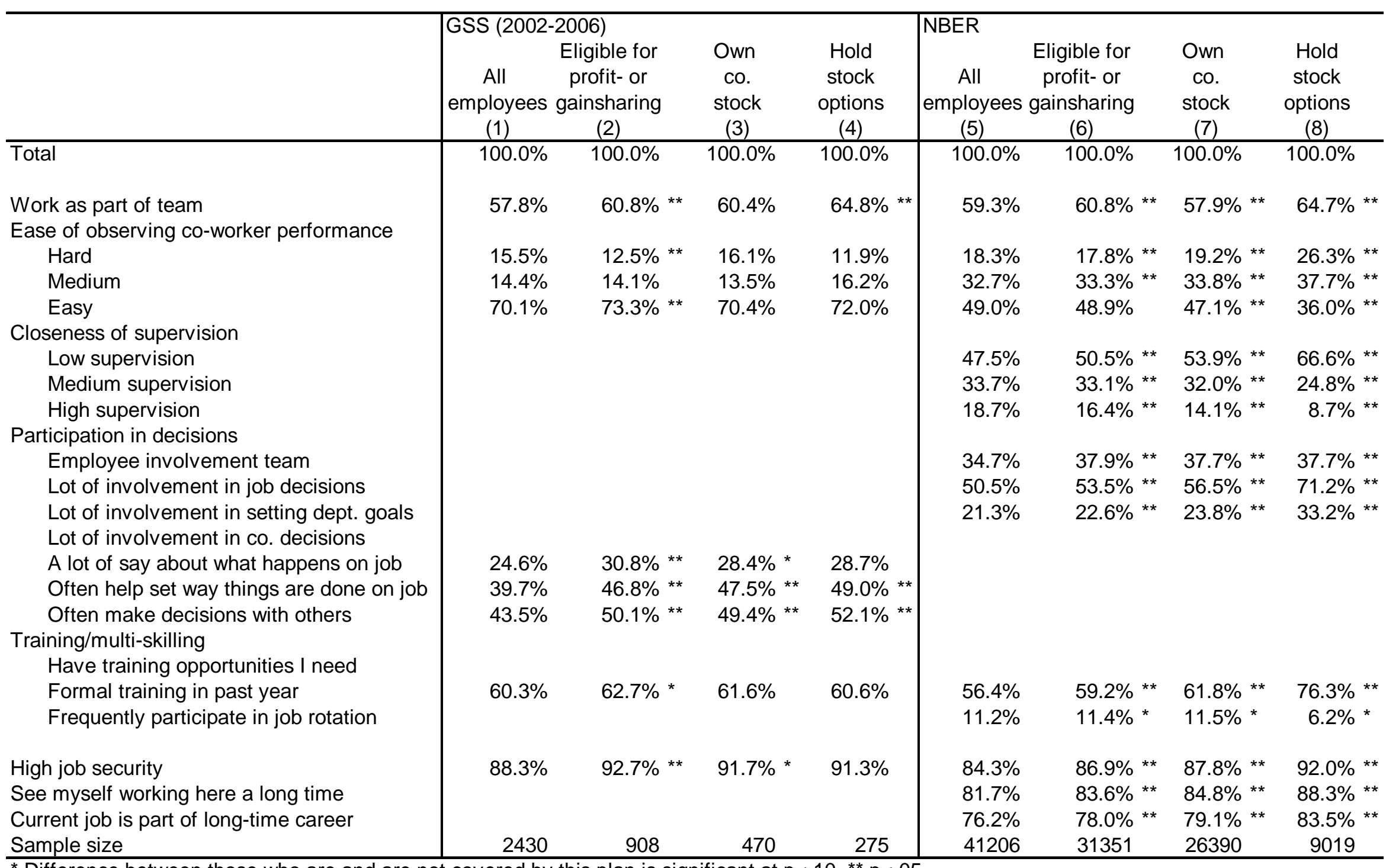

* Difference between those who are and are not covered by this plan is significant at $p<.10$ ** $p<.05$ 


\section{Table 7: Predicting Participation in Shared Capitalism}

Figures are derivatives based on probit regressions, representing effect of one-unit change in independent variable on probability of dependent variable.

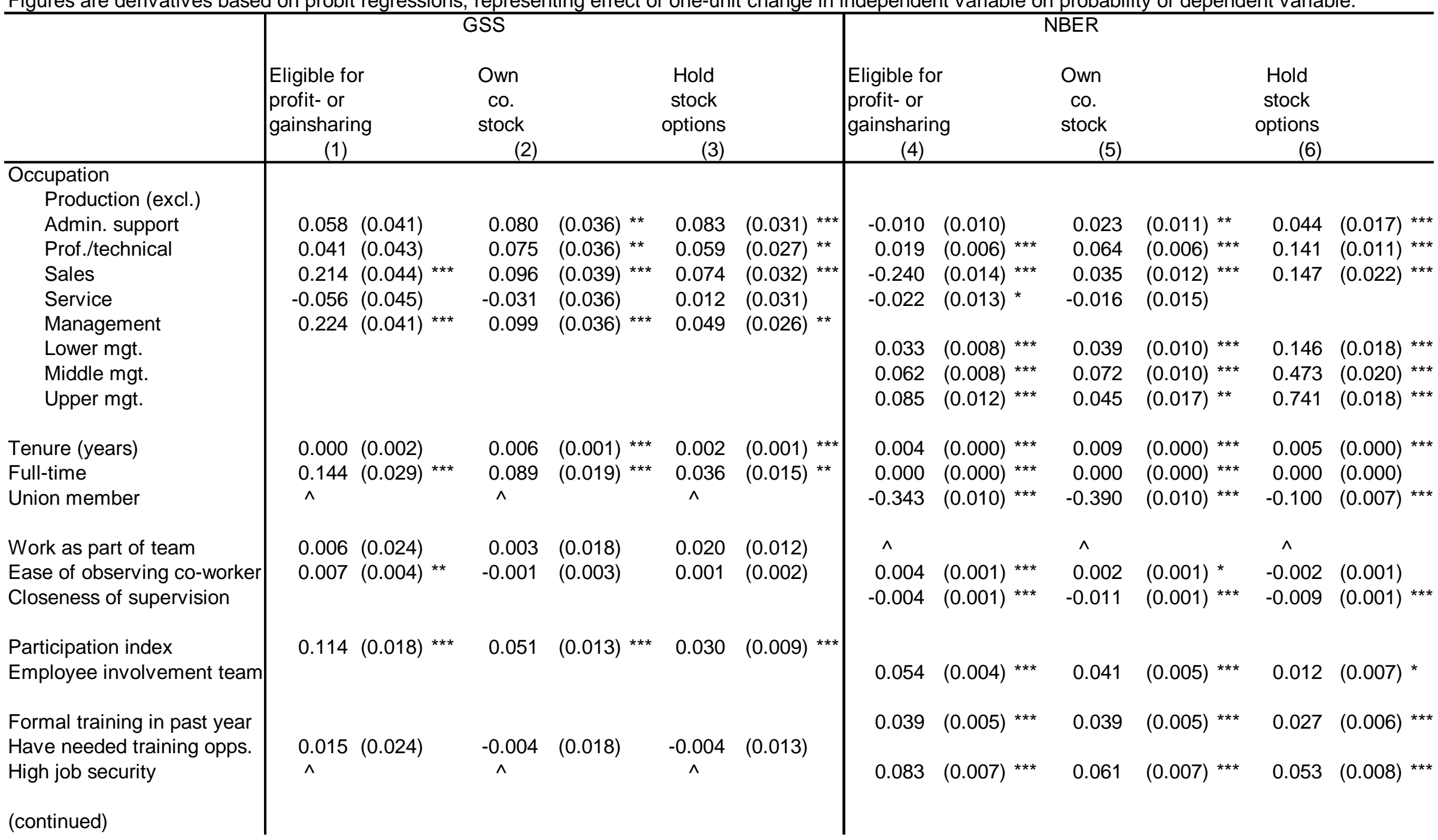




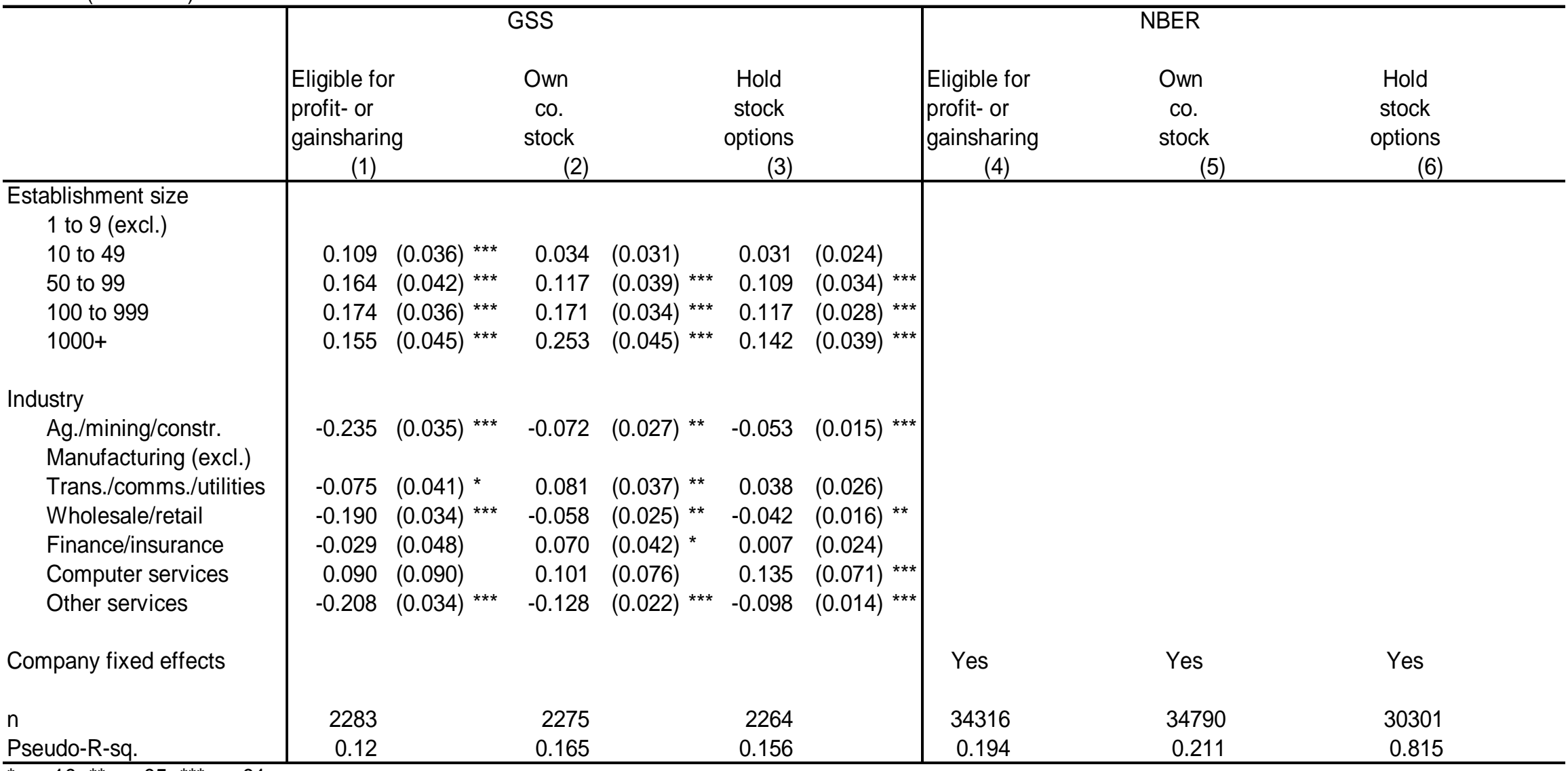

${ }^{*} p<.10{ }^{* *} p<.05{ }^{* * *} p<.01$

$\wedge$ These variables were available only for a limited number of observations. When they are included, the significant relationships are: Union membership in GSS: negative and significant only in column 1

High job security in GSS: positive and significant only in column 1

Work as part of team in NBER: positive and significant in columns 4-6 
Table 8: Risk Aversion and Participation in Variable Pay

\begin{tabular}{|c|c|c|c|c|c|c|c|c|}
\hline Individual bonus eligibility & 6.01 & 5.46 & 0.55 & $(0.03)$ & $* \star *$ & 0.003 & $(0.001)$ & *** \\
\hline Hold stock options & 6.12 & 5.47 & 0.65 & $(0.03)$ & $* \star *$ & -0.001 & $(0.001)$ & * \\
\hline Own co. stock & 5.71 & 5.45 & 0.26 & $(0.03)$ & $* * *$ & 0.003 & $(0.001)$ & ** \\
\hline \multicolumn{9}{|l|}{ Own employer stock through: } \\
\hline Exercising options and keeping stock & 6.11 & 5.59 & 0.52 & $(0.06)$ & $* * *$ & 0.000 & $(0.000)$ & \\
\hline Open market purchase & 6.49 & 5.55 & 0.94 & $(0.05)$ & *** & 0.003 & $(0.000)$ & *** \\
\hline
\end{tabular}

* $p<.10$ ** $p<.05 * \star \star p<.01$

$\wedge$ Controlling for age, gender, marital status (2 dummies),

family size, college graduate, graduate degree, number of kids,

race (4 dummies), disability status, In(fixed pay), In(wealth), and 21 country dummies. 
Table 9: Worker Views of Performance-based Pay

\begin{tabular}{|c|c|c|c|c|c|}
\hline & \multirow[b]{2}{*}{ Overall } & \multicolumn{4}{|c|}{ Risk aversion } \\
\hline & & High & Medium & Low & \\
\hline \multicolumn{6}{|l|}{ Type of pay preferred } \\
\hline All fixed wage or salary & $22 \%$ & $34 \%$ & $25 \%$ & $14 \%$ & $\star \star \star *$ \\
\hline Paid in part with profit sharing, stock, or stock options & $78 \%$ & $66 \%$ & $75 \%$ & $86 \%$ & *** \\
\hline $\mathrm{n}$ & 13199 & 2090 & 5069 & 5953 & \\
\hline \multicolumn{6}{|l|}{ Preference for next pay increase } \\
\hline All profit sharing, stock, and options & $13 \%$ & $12 \%$ & $11 \%$ & $15 \%$ & $\star \star \star *$ \\
\hline $\mathrm{n}$ & 25869 & 5318 & 9805 & 10330 & \\
\hline \multicolumn{6}{|l|}{ Would prefer new bonus plan to be based on (can pick more than one) } \\
\hline Your individual performance & $77 \%$ & $71 \%$ & $77 \%$ & $79 \%$ & $\star \star \star *$ \\
\hline Your workgroup performance & $37 \%$ & $31 \%$ & $36 \%$ & $40 \%$ & $\star \star \star *$ \\
\hline $50 \%$ premium & $41 \%$ & $36 \%$ & $39 \%$ & $45 \%$ & 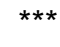 \\
\hline $100 \%$ premium & $64 \%$ & $57 \%$ & $61 \%$ & $68 \%$ & $\star \star \star *$ \\
\hline Reasons for not selling for $50 \%$ premium: & & & & & \\
\hline Like owning company stock & $33 \%$ & $35 \%$ & $33 \%$ & $32 \%$ & \\
\hline Like sense of community from employee ownership & $37 \%$ & $37 \%$ & $36 \%$ & $39 \%$ & \\
\hline Concerned about investor laying off employees & $70 \%$ & $75 \%$ & $73 \%$ & $65 \%$ & $\star \star \star *$ \\
\hline Offer might mean company is worth more & $39 \%$ & $33 \%$ & $38 \%$ & $44 \%$ & *** \\
\hline$x$ & 12938 & 2059 & 4931 & 5854 & \\
\hline \multicolumn{6}{|l|}{ Lower pay accepted for company-based bonus averaging $10 \%$} \\
\hline $\begin{array}{l}\text { Mean percent lower regular pay accepted } \\
\text { (std. dev.) }\end{array}$ & $\begin{array}{r}3.31 \\
(3.56)\end{array}$ & $\begin{array}{r}2.28 \\
(3.21)\end{array}$ & $\begin{array}{r}3.15 \\
(3.51)\end{array}$ & $\begin{array}{r}3.91 \\
(3.63)\end{array}$ & *** \\
\hline
\end{tabular}

* Significant difference among risk groups at $p<.10{ }^{\star \star} p<.05{ }^{* \star \star} p<.01$ 
Appendix Table A1 - Prior Evidence on Prevalence of Shared Capitalism Plans

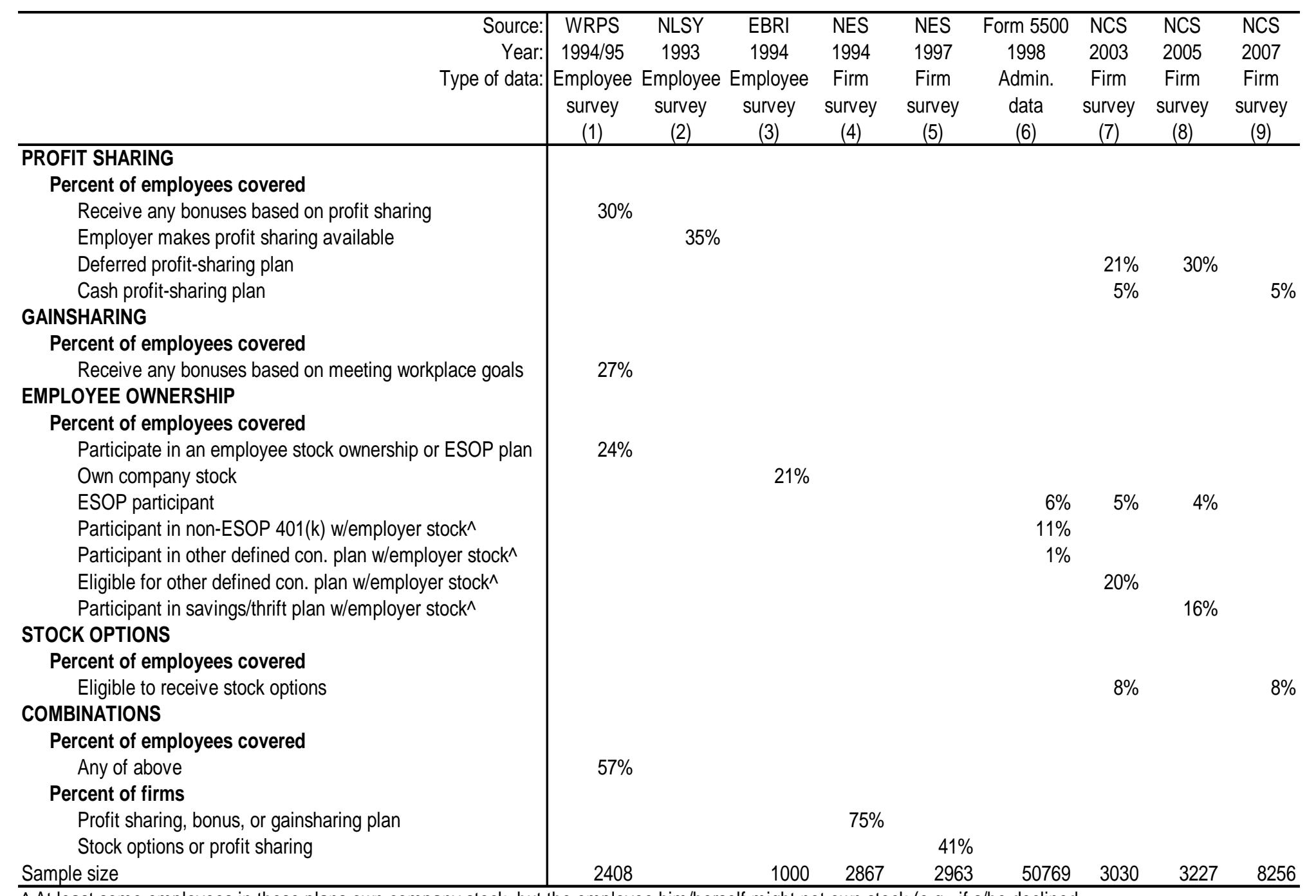

^ At least some employees in these plans own company stock, but the employee him/herself might not own stock (e.g., if s/he declined to allocate some contributions to employer stock in a $401(\mathrm{k}))$

WRPS=Worker Representation and Participation Survey (Freeman and Rogers 1999); NLSY=National Lomgitudinal Survey of Youth (Kruse 1998);

EBRI=Employee Benefits Research Institute (EBRI/Gallup 1994); NES=National Employer Survey (Kruse and Blasi 2000); Form 5500=Form 5500 pension dataset (Kruse 2002); NCS=National Compensation Survey (BLS 2005, 2007, 2008) 
Appendix Table A2: Prior Evidence on Prevalence of Employee Participation in Decisions

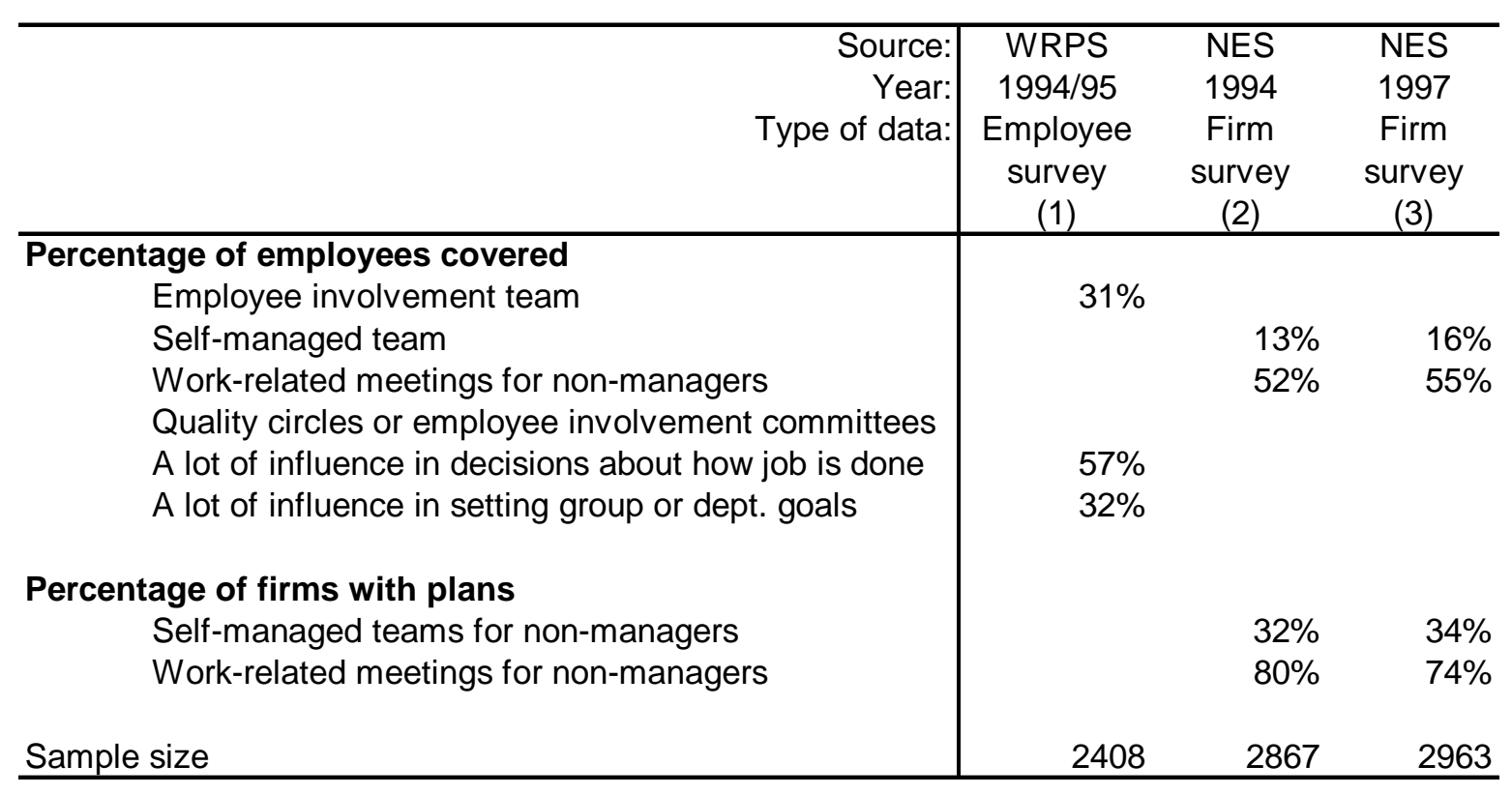

WRPS=Worker Representation and Participation Survey (Freeman and Rogers 1999)(all private sector) NES=National Employer Survey (Kruse and Blasi 2000)(private for-profit firms) 